\title{
Spatial variability of surficial sediments on the northern shelf of the Alboran Sea: the effects of hydrodynamic forcing and supply of sediment by rivers
}

\author{
Variabilidad espacial de los sedimentos superficiales en la \\ plataforma septentrional del Mar de Alborán:influencia del régimen \\ hidrodinámico y del aporte fluvial de sedimentos
}

\author{
P. Bárcenas ${ }^{1 *}$, F. J. Lobo ${ }^{2}$, J. Macías ${ }^{1}$, L. M. Fernández-Salas³, V. Díaz del Río \\ ${ }^{1}$ Dpto. Análisis Matemático, Facultad de Ciencias, Campus de Teatinos, s/n. 29080 Málaga, Spain. \\ E-mail:patricia.barcenas@ma.ieo.es; macias@anamat.cie.uma.es \\ ${ }^{2}$ Instituto Andaluz de Ciencias de la Tierra, CSIC-Universidad de Granada, Avenida de las Palmeras $n^{\circ} 4.18100$ \\ Armilla, Granada, Spain.E-mail: pacolobo@iact.ugr-csic.es \\ ${ }^{3}$ Instituto Español de Oceanografia, Centro Oceanográfico de Málaga, Puerto Pesquero s/n. 29640 Fuengirola, \\ Málaga, Spain.E-mail: luismi.fernandez@ma.ieo.es; diazdelrio@ma.ieo.es
}

*corresponding author

Received: 05/04/11 / Accepted: 19/10/11

\begin{abstract}
Recent surficial sedimentary processes led by hydrodynamic forcing and by laterally variable fluvial supplies are investigated in the eastern shelf of the northern Alboran Sea margin. This study highlights the high spatial variability of sedimentary processes in a relatively small area with an abrupt physiography and subjected to a seasonal and strongly fluctuating climate. We correlate seafloor sediments with backscatter distributions extracted from multibeam echo sounder data; in addition, a wind-forced tidal hydrodynamic model provides flow velocity and derived bed shear-stress values under contrasting wind conditions.

In the study area, the relative proportions of gravel and muds within a dominantly sandy substratum control surficial backscatter intensities. Across-shelf, the only consistent surficial pattern is depicted by a high backscatter intensity, gravelly sandy infralittoral zone, which is subjected to periodic storm activity. Seaward, significant along-shelf changes of the sediment cover and backscatter intensities appear to be controlled at large by a major physiographic feature (the Carchuna Canyon) which separates a western shelf mostly covered by fluvially-derived sediments and an eastern current-controlled shelf. At a finer scale, the seafloor backscatter response outlines three main shelf environments: storm-dominated, mixed and fluvially-dominated. We found that storm-dominated settings are associated with maximum flow velocities and bed shear stress (during both easterlies and westerlies dominance). The distribution of mixed and fluvially-dominated environments is more complex, as it is related to the interaction of less intense hy-
\end{abstract}


drodynamic conditions with laterally changing fluvial supplies from mountainous, short rivers and streams. As a consequence, the surficial sedimentary fingerprints of the two most important regional rivers (Guadalfeo and Adra) are significantly different.

Keywords: Alboran Sea, shelf, surficial sediments, backscatter, hydrodynamic model

\section{Resumen}

El estudio de los procesos sedimentarios superficiales recientes, gobernados por el régimen hidrodinámico y por los aportes fluviales lateralmente variables, se ha llevado a cabo en la plataforma continental del margen norte del Mar de Alborán. Este trabajo pretende resaltar la elevada variabilidad lateral de dichos procesos en un área relativamente reducida, caracterizada por una abrupta fisiografía y un régimen climático estacional. Se ha realizado la correlación de los datos de sedimento superficial con la distribución de la reflectividad extraída a partir de los datos de ecosonda multihaz; además, se ha implementado un modelo hidrodinámico que proporciona datos de velocidad media de la corriente e indirectamente de tensión tangencial en el fondo bajo diferentes condiciones de vientos.

En el área de estudio, los contenidos en grava y fango en un substrato principalmente arenoso, parecen controlar los valores superficiales de intensidad de la reflectividad. Transversalmente, el único patrón superficial consistente está dado por altos valores de reflectividad generados por un infralitoral arenoso (con alto contenido en gravas) sometido a la actividad periódica de tormentas. Mar adentro, se observan cambios longitudinales significativos en la cobertera sedimentaria y en los valores de la reflectividad, los cuales se encuentran controlados por el principal rasgo fisiográfico regional (el Cañón de Carchuna), el cual delimita un sector occidental cubierto principalmente por sedimentos de origen fluvial y un sector oriental controlado por el sistema de corrientes A menor escala, los valores de backscatter del fondo marino definen tres ambientes principales en la plataforma: el dominado por tormentas, el mixto y el dominado por la influencia fluvial. El primero de ellos viene definido por las máximas velocidades de corriente y de tensión tangencial en el fondo, tanto bajo condiciones de vientos de poniente como de levante. La distribución de los ambientes mixtos y dominados por la influencia fluvial es más compleja, debido a la combinación de condiciones hidrodinámicas de menor intensidad con una gran variabilidad lateral del aporte fluvial preveniente de ríos cortos y montañosos y ramblas. Como consecuencia, la huella sedimentaria superficial de los dos ríos regionales más importantes (Guadalfeo y Adra) presenta patrones diferenciados.

Palabras clave: Mar de Alborán, plataforma continental, sedimentos superficiales, reflectividad, modelo hidrodinámico

\section{Introduction}

Since the inception of multibeam echo sounders (MBES) as a primary procedure for sea-floor mapping and exploration of shallow environments, the analysis of backscatter strengths has been a valuable tool for obtaining meaningful information about sea-floor sediment distribution, composition and geological processes (Glynn et al., 2008; Medialdea et al., 2008). By extension, it enables the determination of benthic habitats, the monitoring of natural and/or anthropogenic changes and the interpretation of dynamic characteristics of water masses (e.g., Kostylev et al., 2001; Glynn et al., 2008).

Backscatter intensity is modulated by the interaction of several parameters (Jackson et al., 1986; Gadner et al. 1991) such as surface and volume scattering, the angle of incidence of the incoming acoustic wave to the seafloor and the acoustic impedance contrast of the sub bottom sediment interfaces. The effect of the referred parameters on the backscatter data in order to obtain quantitative information about the seafloor materials has been studied by a number of authors (Jackson et al., 1986; Gadner et al., 1991; Mitchell, 1991, 1993; 1995). Within those factors, surface scattering is particularly significant for retrieving geological and environmental information from seafloor data, as it is mainly dependant on surface roughness, which may be produced by a number of sedimentological, physiographic and biological properties (Collier and Brown, 2005). Sediment-related factors would include grain size, density, composition and sediment structures (Collier and Brown, 2005; De Falco et al., 2010). Physiographic factors depend on sea-floor roughness generated by rock outcrops or small-scale bedforms (Glynn et al., 2008). Biological factors comprise bioturbation and the presence of benthic organisms (De Falco et al., 2010).

Grain size distributions on continental shelves constitute the leading control on sea-floor response to acoustic imaging (Hamilton and Bachman, 1982), as in general grain size distributions show positive correlations with mean backscatter intensities (Kostylev et al., 2001; Collier and Brown, 2005; Lathrop et al., 2006; De Falco et al., 2010). Thus, rocks and coarse sediments tend to produce high scatter (Mitchell and Hughes Clarke, 1994; Goff et al., 2000; Glynn et al., 2008). Medium to low backscatter is generally associated with finer-grained muddy sediments (Mitchell and Hughes Clarke, 1994), due to low density and sound velocity (Ferrini and Flood, 2006). In addition, sediment-controlled distributions are correlated with physiography-induced surface roughness, as the roughest sea-floor areas normally correspond with rock outcrops, whereas muddy sediments tend to generate smooth seafloors (Glynn et al., 2008). This correla- 
tion has been found to be particularly robust in the case of well-sorted sediments, as poorly-sorted sediments show more variable backscatter responses (Goff et al., 2000; Collier and Brown, 2005). Disturbing effects on the expected grain size-backscatter correlation may be caused by a number of physiographic and biological factors. For example, the presence of small-scale bedforms and bioturbation may increase surface roughness (Glynn et al., 2008); as a consequence, fine-grained areas may be characterized with high backscatter (Urgeles et al., 2002). The presence of benthic organism may also be significant, as they can produce gas bubbles that mask the underlying substrate (De Falco et al., 2010). However, those effects would not be significant at high sonar frequencies because of the high attenuation coefficients of muds (Mitchell, 1993).

Shallow shelves represent one of the environments where backscatter variability can be more directly linked to grain size, due to their low bathymetric changes. As thus, most of the approaches acknowledge that seabed properties can be extracted from digital backscatter/side scan sonar data, while accompanied by ground-truth data

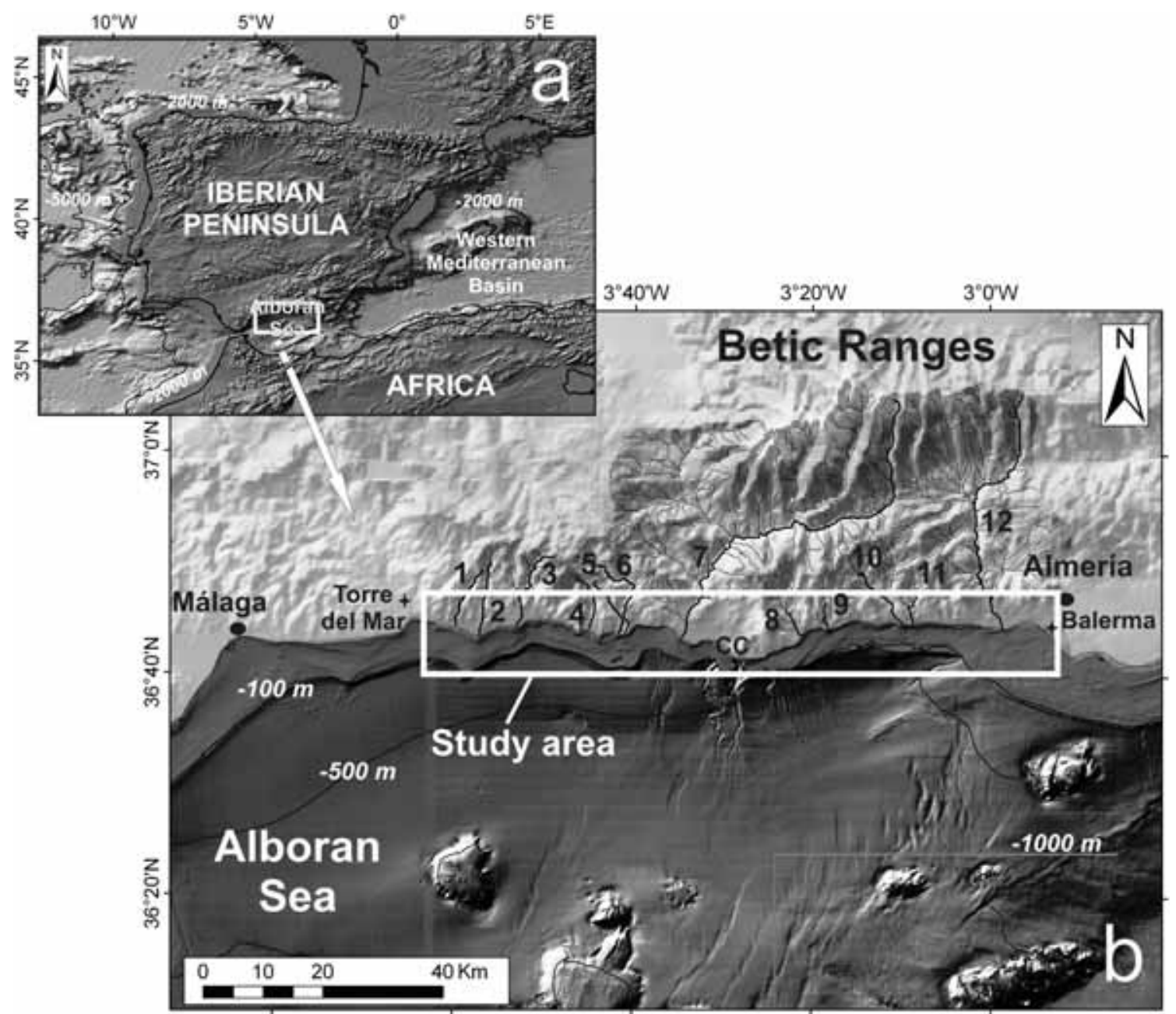

Fig.1.- Geographical location of the study area: (a) emplacement of the Alboran Sea, the westernmost sector of the western Mediterranean Basin, between the Iberian Peninsula and Africa (image generated from ETOPO database); (b) the study area is located in the northern margin of the Alboran Sea, off the Betic Ranges (the onland physiography is extracted from the Digital Terrain Model of the "Junta de Andalucía" and the submarine bathymetry is extracted from the Alboran Sea submarine database of the "Secretaría General del Mar"). The main fluvial systems in the study area include rivers such as Güí (1), Torrox (2), Chillar (3), Jate (4), Seco (5), Verde (6), Guadalfeo (7) and Adra (12), and streams such as Gualchos (8), Haza de Trigo (9), Albuñol (10) and Huarea (11). CC stands for Carchuna Canyon.

Fig. 1.- Localización geográfica del área de estudio (a) ubicada en el Mar de Alborán, el sector más al oeste de la Cuenca Mediterránea occidental, entre la Península Ibérica y África (imagen generada de la base de datos ETOPO). (b) Concretamente, el área de estudio se encuentra en el margen norte del Mar de Alborán, frente a las Cordilleras Béticas (la fisiografía de tierra ha sido extraída del Modelo Digital del Terreno de la Junta de Andalucía y la batimetría submarina del Mar de Alborán pertenece a la base de datos de la Secretaría Genral del Mar. Los principales sistemas fluviales observados en el área se indican con los siguientes números: (1-7 y 12): Ríos Güí, Torrox, Chillar, Jate, Seco, Verde, Guadalfeo y Adra, y (8-11): Ramblas de Gualchos, Haza de Trigo, Albuñol y Huarea. CC: Cañón de Carchuna. 


\begin{tabular}{|c|c|c|c|c|c|c|c|c|c|c|c|c|}
\hline RIVER SYSTEM NAME & 誌 & $\stackrel{\overrightarrow{0}}{\stackrel{0}{0}}$ & 竎 & $\stackrel{\Xi}{\Xi}$ & $\begin{array}{l}\dot{\Xi} \\
\ddot{E}\end{array}$ & $\frac{\mathscr{c}}{\partial 0}$ & 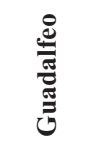 & Uू & 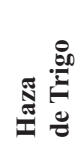 & 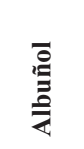 & 莺 & $\frac{\pi}{4}$ \\
\hline Basin area $\left(\mathbf{k m}^{2}\right)$ & 57.9 & 50 & 55.7 & 31.89 & 21.4 & 100.6 & 1312.2 & 74.7 & 24.2 & 118.1 & 40.8 & 750.7 \\
\hline Basin maximum elevation (m) & 1427 & 1534 & 1588 & 1363 & 1069 & 1624 & 3243 & 1755 & 1378 & 1335 & 1172 & 2682 \\
\hline River length (km) & 14.5 & 17.5 & 16.2 & 11.3 & 10.5 & 23.4 & 72.5 & 13.4 & 8.7 & 20 & 12.3 & 51.4 \\
\hline River slope (degree) & 2.91 & 4.74 & 5.02 & 6 & 2.91 & 3.66 & 2.38 & 4.57 & 8.19 & 3.6 & 5.19 & 2.51 \\
\hline River maximum elevation (m) & 749 & 1457 & 1428 & 1224 & 533 & 1502 & 2793 & 1080 & 1267 & 1267 & 1120 & 2277 \\
\hline Mean precipitacion $\left(\mathrm{mm} \mathrm{yr}^{-1}\right)$ & - & 657.3 & - & - & - & 747.5 & 717.3 & - & - & - & - & 445.1 \\
\hline Mean discharge $\left(\mathrm{m}^{3} \mathbf{s}^{-1}\right)$ & - & 0.2 & - & - & - & 0.3 & 3.3 & - & - & - & - & 1 \\
\hline Discharge historical maximun $\left(\mathrm{m}^{3} \mathrm{~s}^{-1}\right)$ & - & 0.6 & - & - & - & 5.3 & 59.47 & - & - & - & - & 24.12 \\
\hline Mean runoff $\left(1 \mathrm{~km}^{-2} \mathbf{s}^{-1}\right)$ & - & 3.9 & - & - & - & 2.8 & 0.4 & - & - & - & - & 1.3 \\
\hline Runoff historical maximum $\left(1 \mathrm{~km}^{-2} \mathrm{~s}^{-1}\right)$ & - & 12.2 & - & - & - & 52.2 & 5.3 & - & - & - & - & 21.7 \\
\hline Mean sediment load $\left(\mathrm{kg} \mathrm{s}^{-1}\right)$ & - & 0.1 & - & - & - & 0.4 & 2.7 & - & - & - & - & 4.8 \\
\hline
\end{tabular}

Table 1: Watershed characteristics, rivers hydrology and sediment supply from the main fluvial systems located in the study area (extracted from Liquete et al. (2005)).

Tabla 1: Resumen de las características de las cuencas hidrográficas, hidrología y aporte sedimentario de los principales sistemas fluviales localizados en el área de estudio (extraído de Liquete et al. (2005)).

such as surficial sediment samples (Kostylev et al., 2001; Lathrop et al., 2006; Glynn et al., 2008; Brown et al., 2011). In addition, sediment dynamics and bottom sediment properties are supposed to be largely influenced by shelf bottom flows. The aim of this contribution is to establish the leading controls of present-day surficial sedimentary processes in a sector of the northern Alboran Sea shelf influenced by episodic fluvial supplies and alternating winds. To accomplish that main goal, a correlation between surficial backscatter data and grain-size distributions has been attempted, in order to link the classified backscatter with the relative percentages of gravel, sand and mud in surficial sediments. In addition, seafloor sediment properties have been compared with hydrodynamic parameters (i.e., depth-averaged current velocities and bed shear stress) derived from a mathematical model.

\section{Study area}

\subsection{Geological setting}

The study area is located in the northern margin of the Alboran Sea, western Mediterranean Sea, comprising the shelf stretch between Torre del Mar and Balerma towns (Fig. 1). The Alboran Basin is located along the EurasiaAfrica plate boundary, and it is surrounded by the BeticRif Arc. The Alboran Sea was structured during the the Oligocene-late Miocene through a number of rifting stages (Comas et al., 1992). Since the Tortonian, however, the basin has been subjected to convergence between Eurasia and Africa. Most of the previous structures have been reactivated as strike-slip faults (Campillo et al., 1992; Estrada et al., 1997).
The shelf of the northern Alboran Sea margin is narrow (several kilometers wide), although it may reach locally more than $20 \mathrm{~km}$ in width off Málaga and Almería, due to the sediment supply of major rivers (Muñoz et al., 2008). The shelf break is located at a mean water depth of 110 $\mathrm{m}$ (Vázquez, 2001). The most significant inner shelf morphologies include prodeltaic bodies in front of the main fluvial inputs and infralittoral prograding wedges (IPWs) laterally from the main fluvial entries. Wide segments of the outer shelf are covered either by sand ridges or by erosional and/or tectonic morphologies such as abrasion surfaces, submarine terraces and escarpments (Hernández-Molina et al., 1994, 1996; Vázquez, 2005; Lobo et al., 2006). The most significant erosive feature in the study area is the Carchuna Canyon head, which is located at less than $500 \mathrm{~m}$ from the coastline off Cape Sacratif and cuts the entire shelf with a main N-S trend, showing several distributaries (Lobo et al., 2006).

\subsection{Oceanographic regime}

Tides are determined by the entrance of Atlantic waters across the Strait of Gibraltar with a main semidiurnal periodicity (Parrilla and Kinder, 1987). Dominant wind directions alternate from the west and from the east, generating a low-to-moderate wave climate (Puertos-delEstado, 2007).

The location of the Alboran Sea to the east of the Strait of Gibraltar greatly influences its oceanography, as surface current patterns are controlled by the entrance of Atlantic waters designed either the Atlantic Inflow (AI) or Surface Atlantic Water (SAW) through the strait with an estimated speed of $1 \mathrm{~m} \mathrm{~s}^{-1}$. The AI is mixed with vari- 
able amounts of water masses of Mediterranean origin generating the Atlantic Jet (AJ) that feeds two anticyclonic gyres, the quasi-permanent Western Alboran Gyre (WAG) and the more elusive Eastern Alboran Gyre (EAG) (Tintoré et al., 1988; Perkins et al., 1990). The AJ originates a strong thermohaline front between cold and dense Mediterranean waters to the left and Atlantic waters to the right of the jet (Vargas-Yáñez and Sabatés, 2007).

\subsection{Sediment sources and surficial sediments}

In deltaic coastlines of the northern Alboran Sea margin most sediments are supplied via relatively short, mountainous rivers and streams. In the study area, the rivers and streams can be classified according to several parameters, such as basinal areas, river lengths and slopes, water discharges and sediment loads, in the following types (Fig. 1): (a) major rivers (Guadalfeo and Adra); (b) minor rivers (Güí, Torrox, Chillar, Jate, Seco and Verde), which are mostly located in the western part of the study area; (c) discontinuous streams (Gualchos, Haza de Trigo, Albuñol and Huarea), which do not have a permanent flow and are preferentially located to the east of the Carchuna Canyon (Table 1). Overall, mean discharges decrease from west to east, but in contrast mean sediment loads and yields tend to increase to the east, indicative of an increasing torrential character (Liquete et al., 2005). This supply pattern is conditioned by: (a) the abrupt coastal physiography, as the Betic Mountains occur at short distance from the coast, and in several places show recent tectonic activity leading to steepening of physiographic profiles and river incision (Carvajal and Sanz de Galdeano, 2008); (b) the Mediterranean climate, with increasing aridity toward the east. Due to the torrential character, most of the rivers are very effective in transporting sediments from the drainage basins toward the shelf and eventually into deeper water (Liquete et al., 2005).

Littoral drift shows a high variability, although eastward drift is more common (Lario et al., 1999; Goy et al., 2003) due to the interaction between prevailing waves and coastline configuration. Beach ridges and spit bars have been constructed during the Holocene highstand in coastal sectors dominated by along-shore processes (Lario et al., 1999; Goy et al., 2003).

Sedimentation is siliciclastic in the western and central parts of the northern shelf of the Alboran Sea. Siliciclastic sediments are mainly derived from suspended load deposition, developing muddy prodeltaic facies with coarsening-fining upward sequences and variable amounts of sands (Ercilla et al., 1994). The sediments are transported laterally either by littoral drift or by AI influence. Postglacial relict sediments composed of reworked sands and gravels carpet the outer shelf (Ercilla et al., 1994; Hernández-Molina et al., 1994). Spillover facies mainly composed by sands tend to occur in the proximity of the shelf break; these facies are related to reworking and resuspension by storm currents and by upper slope gravitational processes (Ercilla et al. 1994).

\section{Methodology}

This study is based on the integration of both observational data (surficial sediments and backscatter data) and model simulation results.

\subsection{Surficial sediment samples}

62 surficial sediment samples were collected with a Van Veen dredge during two geological surveys (ESPACE01

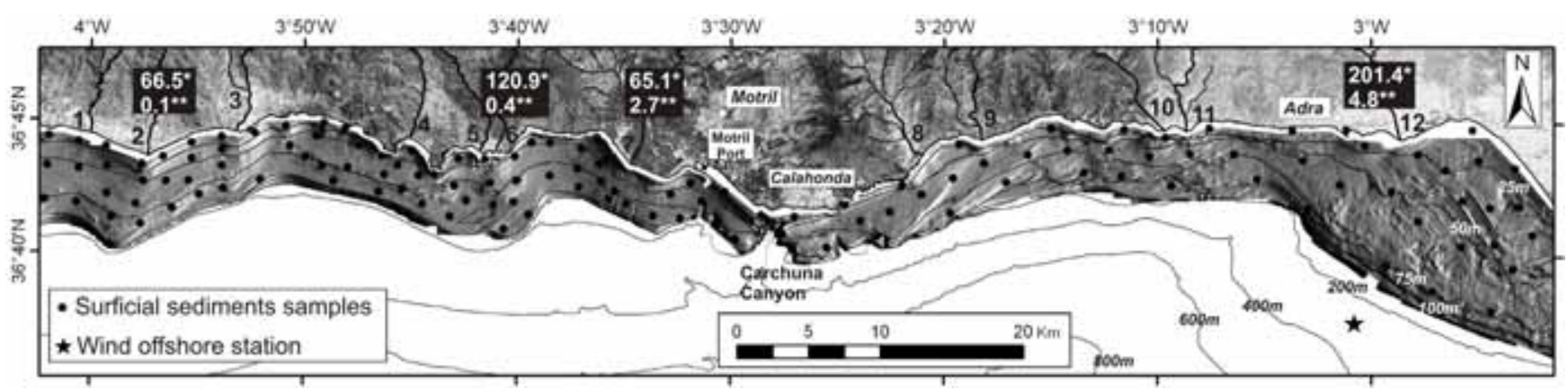

Fig. 2.- Location of surficial sediments samples in the study area. The position of the offshore wind station is also indicated. The shadedrelief map shows the multibeam coverage used for this study. Fluvial systems are indicated by numbers 1-12. See location in Fig. 1. Legend: *Mean sediment yield $\left(\mathrm{t} \mathrm{km}^{-2} \mathrm{yr}^{-1}\right)$ and **Mean sediment load $\left(\mathrm{kg} \mathrm{s}^{-1}\right)$.

Fig. 2.-. Localización de las muestras de sedimento superficial en el área de estudio. Se indica también la posición de la estación de los datos de viento. El mapa de sombras muestra el área de muestreo de la ecosonda multihaz utilizada para este estudio. Los sistemas fluviales se indican con los números del 1-12. Ver localización en la Fig. 1. Leyenda: * Aporte medio de sedimento $\left(\mathrm{t} \mathrm{km}^{-2}\right.$ año $\left.{ }^{-1}\right) \mathrm{y}^{* *}$ Descarga media de sedimentos $\left(\mathrm{kg} \mathrm{s}^{-1}\right)$. 

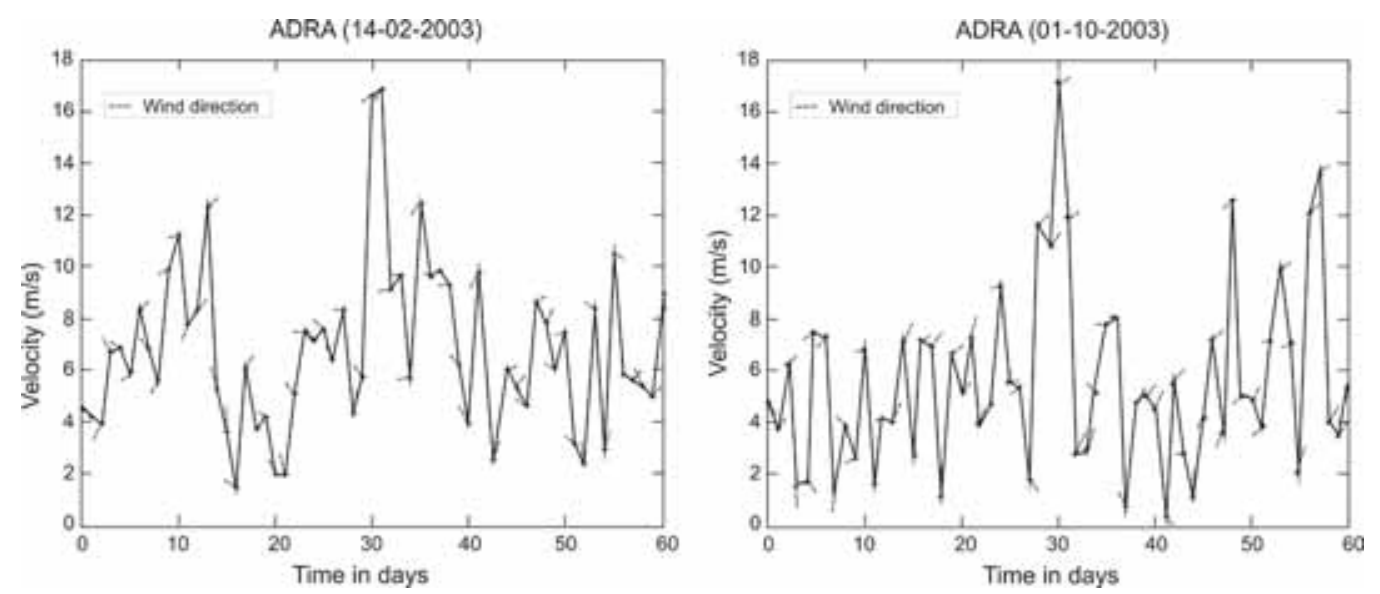

Fig. 3.- Wind data from Puertos del Estado (2007) implemented in the model, by considering two periods with contrasting wind dominance (to the left, period with easterlies dominance; to the right, period with westerlies dominance).

Fig. 3.- Datos de viento procedentes de Puertos del Estado (2007) implementados en el modelo, considerando dos periodos con vientos dominantes de direcciones opuestas (a la izquierda, periodo con vientos dominantes de levante; a la derecha periodo con vientos dominantes de poniente).

and ESPACE02) (Fig. 2). Spacing between adjacent sediment samples is between 0.5 and $5 \mathrm{~km}$. The granulometric analysis involved the coarse $(\varnothing>63 \mu \mathrm{m})$ and the fine-grained $(\varnothing<63 \mu \mathrm{m})$ fractions. The textural composition of surficial sediment samples has been obtained by representing gravel, sand and mud fraction percentages in Folk's ternary diagrams $(1954,1974)$. We mapped the distribution of surficial sediment types in the study area, as well as the spatial distribution of the percentages of the mud, sand and gravel fractions.

\subsection{Backscatter data}

Backscatter data were collected by using a $300 \mathrm{kHz}$ Simrad EM3000D MBES during several geological surveys (ESPACE01 and ESPACE02). The EM3000D echosounder generates 254 beams $\left(1.5^{\circ} \times 1.5^{\circ}\right.$ wide, $0.9^{\circ}$ spacing) that includes bathymetric information in a ten times water depth wide band, with a maximum ping rate of 25 Hz. Backscatter data were processed with the Neptune ${ }^{\mathrm{TM}}$ software at a $5 \times 5 \mathrm{~m}$ grid. The grid was filtered by applying an ArcGISTM software statistical filter that calculated the mean backscatter value each $180 \mathrm{~m}$, assuming (1) this value as the horizontal MBES resolution and (2) the application of a perpendicular angle to the direction of the boat during data acquisition. The backscatter intensity has been represented by a colour scale, ranging from blue (high intensity) to red (low intensity).

Backscatter classification was performed through the establishment of intervals of intensity values by using the ArcGISTM software. Those intervals were generated by using the Jenks Natural Breaks Classification (or Op- timization) system, which is a data classification method designed to optimize the arrangement of a set of values into natural classes, as the method reduces the variance within classes and maximizes the variance between classes (Jenks, 1967; McMaster, 1997). In our case, the acoustic data are not completely quantitative, due to the lack of correction of the different controlling parameters (Jackson et al., 1986; Gadner et al. 1991). This study is mainly based on the data correlation obtained with different techniques instead of detailed backscatter data analysis.

\subsection{Hydrodynamic model}

To reproduce shelf hydrodynamic conditions, a number of numerical experiments were performed by using a finite volume shallow-water hydrodynamical model (Castro el at., 2006). The numerical model was run with initial calm conditions by imposing variable in time and constant in space winds at the sea surface and tidal forcing at the open sea boundaries. Sea surface elevation and the two horizontal components of the mean flow velocity were obtained.

Wind forcing derives from observational data of the WANA station located off the Adra River (Puertos del Estado, 2007) (Fig. 2). The WANA data set is formed by time series of wind and wave parameters generated from numerical modeling. In order to run the model, two periods with contrasting wind conditions were selected: a 61-day period of prevailing easterly winds starting at $14^{\text {th }}$ February 2003 and a 60 -day period of prevailing westerly winds starting at $1^{\text {st }}$ October 2003 (Fig.3). Within 
each period, we focus on hydrodynamic conditions related to high-energy storm events (wind velocities higher than $6 \mathrm{~m} \mathrm{~s}^{-1}$ ). To produce a smooth transition from daily observed data, model imposed winds were continuously interpolated in time.

At the open sea boundaries of the computational domain, boundary conditions that simulate tidal elevation are imposed as:

$$
h\left(x_{B}, y_{B}, t\right)=\underline{h}_{B}+\sum_{t=1}^{4} A_{n}\left(x_{B}, y_{B}\right) \cos \left(\omega_{n} t-a_{n}\right)
$$

where $\left(x_{B}, y_{B}\right)$ define a point of the open boundaries, $\underline{h}_{B}=h\left(x_{B}, y_{B}\right)$ the water depth at the steady-state solution at this point, $\mathrm{A}_{\mathrm{n}}\left(\mathrm{x}_{\mathrm{B}}, \mathrm{y}_{\mathrm{B}}\right)$ the amplitudes, $\omega_{\mathrm{n}}$ the frequencies, and $a_{n}$ the phases of the four tidal components considered (M2, S2, O1 and K1). The total phase $a_{n}$ is decomposed into $a_{n}=g_{n}+V_{n}\left(t_{0}\right)$, with $g_{n}$ the Greenwich phase and $\mathrm{V}_{\mathrm{n}}\left(\mathrm{t}_{0}\right)$ the astronomical argument. The latter is used to initiate the forcing at a given date. Amplitudes, frequencies and Greenwich phases were extracted from FES2004 (Lyard et al., 2006). Astronomical phases were computed in order to initiate the tidal forcing at the starting dates of each of the two simulations (02/14/2003 and 01/10/2003) to produce more realistic and coherent results.

\subsection{Bed shear stress}

The bed shear stress or bottom friction $\left(\tau_{0}\right)$ was computed using the formula proposed by Soulsby (1997):

$$
\tau_{0=} \rho u_{*}^{2} \tau_{0=} \rho u_{*}^{\mathbf{z}} \tau_{0=} \rho u_{*}^{\mathbf{*}}
$$

where $\rho=1027 \mathrm{~kg} \mathrm{~m}^{-3}$ and the friction or shear velocity $\left(\mathrm{u}_{*}\right)$ is defined by:

$$
u_{*}=0.121\left(\frac{d_{50}}{z}\right)^{1 / 7} u_{z}
$$

where $d_{50}$ is the median grain diameter, $z$ is the height above the sea bed (in this study $=1 \mathrm{~m}$ ) and $u_{z}$ is the current velocity at a height of $\mathrm{z}$ meters above the sea bed, defined by Soulsby (1997) as:

$$
u(z)=\left(\frac{z}{0.32 h}\right)^{1 / 7} \bar{u}
$$

for $0<z<0.5 h$, where $\bar{u}$ is the depth-average current speed obtained by the wind-forced tidal hydrodynamic model and $h$ is the water depth.

\section{Shelf surficial sediment distribution}

Seven sediment types have been found in the study area: sandy gravel, muddy sandy gravel, gravely sand, sand, gravely muddy sand, muddy sand and sandy mud
(Fig. 4). The most common sediment type is muddy sand (Fig. 4), with sand contents $>70 \%$ over most of the study area (Fig. 5b). In shallow waters $(<25 \mathrm{~m})$, the sediments are mainly composed by sandy gravels and sands (Fig. 4). From $25 \mathrm{~m}$ water depth to the shelf break (>100 m) all the granulometric classes are present, although muddy sandy gravels and sandy gravels show very limited occurrence (Fig. 4). As a general rule, the sediments of the study area show seaward decreasing gravel contents and seaward increasing mud contents (Fig. 5). As there are significant along-shelf changes of surficial sediments, the study area was subdivided in two sectors (western and eastern) limited by the Carchuna Canyon (Fig. 4).

\subsection{Western sector}

The dominance of muddy sands is particularly evident in this sector, where a seaward gradation of sediment sizes is usually found (Fig. 4a). Muddy sands show sand percentages generally higher than $50 \%$ and mud percentages are below $40 \%$ (Figs. 5a, 5b).

There are shelf zones of finer or coarser grain sizes of limited extend. A patch of sandy mud with mud percentages higher than $50 \%$ occurs between the Verde and Guadalfeo rivers (Fig. 4a). The zones with coarser grain sizes occur: (a) off the Torrox River, where gravelly sands extend across the shelf with sand contents higher than $80 \%$ and gravel contents below $15 \%$; (b) off the Chillar River, where sands form a cross-shelf strip extending from the river mouth to the shelf break; (c) over the infralittoral between the Chillar and Verde rivers and between the Motril Port and the Carchuna Canyon (Figs. $4 a, 5)$, where sandy gravels show maximum gravel percentages higher than $40 \%$.

\subsection{Eastern sector}

The shelf is characterized by higher grain sizes to the east of the Carchuna Canyon, as gravelly sands and sands occur over widespread zones (Fig. 4b), although muddy sands are also widely distributed. Mud contents are considerably lower than in the western sector, showing in many zones percentages lower than 15\% (Fig. 5c).

Gravelly sands with sand contents higher than $70 \%$ and gravel contents below $25 \%$ cover extensive mid to outer shelf zones between the Carchuna Canyon and the Haza de Trigo Stream (Figs. 4b, 5a, 5b).

Muddy sands cover inner shelf zones to the east of Calahonda town, extending over the entire shelf with mud percentages up to $50 \%$ between the Haza de Trigo and Albuñol streams. Muddy sands are restricted to mid-shelf water depths off the Huarea Stream, being substituted to 

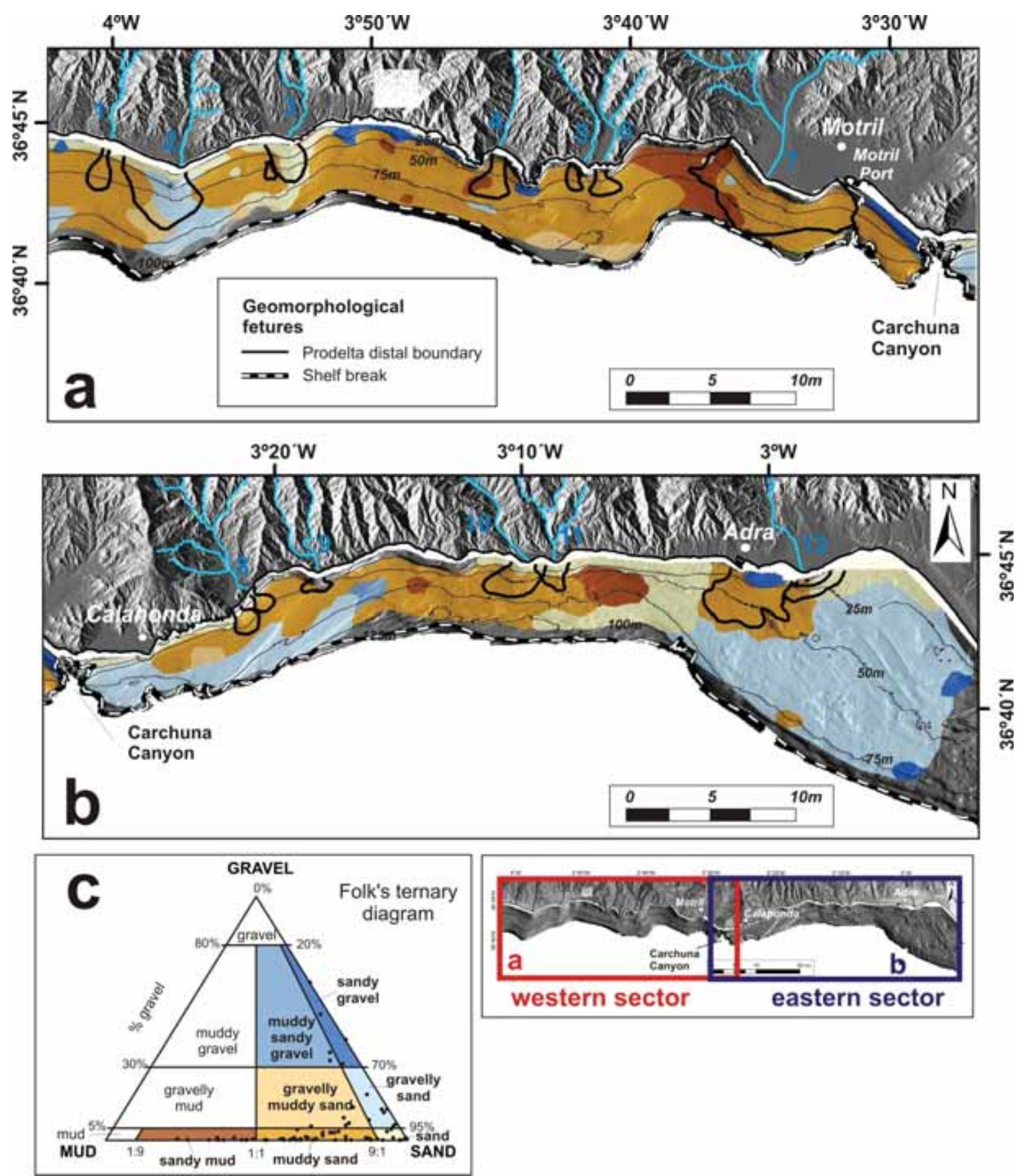

Fig. 4.- Distribution map of surficial sediments in the study area: (a) Western sector and (b) Eastern sector). c) The ternary diagram of Folk $(1954,1974)$ with plotted samples is displayed for clarification. Fluvial systems are indicated by numbers 1-12. See location in Fig. 1.

Fig. 4.- Cartografía del sedimento superficial del área de estudio: (a) sector occidental y (b) sector oriental. c) Diagrama textural de Folk $(1954,1974)$ donde se representan las muestras utilizadas para la caracterización textural del sedimento. Los sistemas fluviales se indican con los números del 1-12. Ver localización en la Fig. 1.

the east by a small patch of sandy muds with mud percentages higher than $50 \%$ (Figs. $4 \mathrm{~b}, 5 \mathrm{c}$ ).

Most of the shelf to the east of the Huarea Stream is covered by coarser sediments, such as sands (with sand contents higher than $80 \%$ ), gravelly sands (with sand contents higher than $70 \%$ and gravel contents below $25 \%$ ) and small isolated patches of sandy gravels (with gravel contents higher than $40 \%$ ) located over the topsets of the Adra River prodelta and in the eastern termination of the study area (Figs. 4b, 5). Finer sediments occur off the Adra River where a muddy sand patch covers the prodeltaic protuberance (Fig. 4b). 

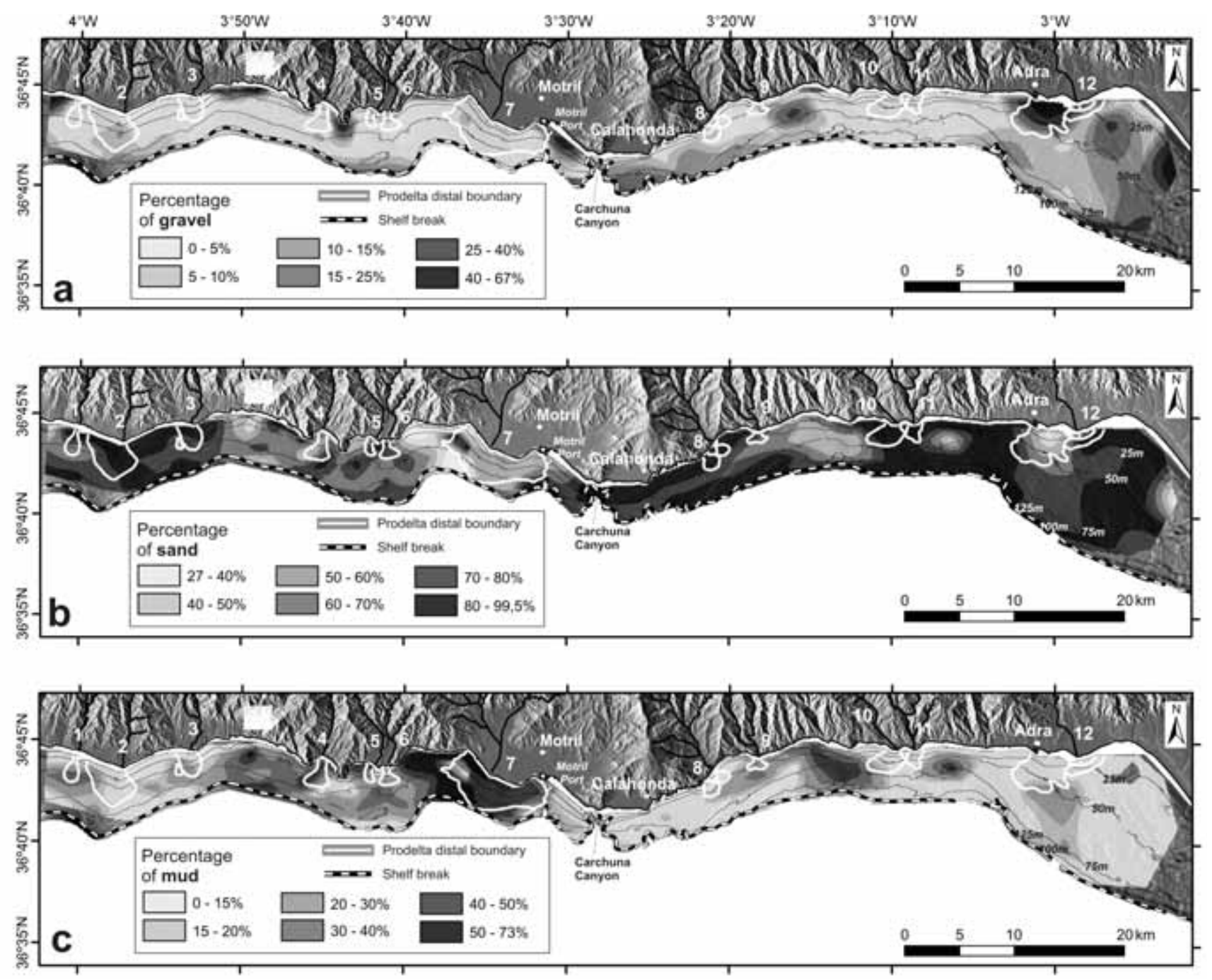

Fig. 5.- Percentage distribution maps of gravel (a), sand (b) and mud (c) of surficial sediments in the study area. Fluvial systems are indicated by numbers 1-12. See location in Fig. 1.

Fig. 5.- Cartografías del contenido en grava (a), arena (b) y fango (c) de los sedimentos superficiales en la zona de estudio. Los sistemas fluviales se indican con los números del 1-12. Ver localización en la Fig. 1.

\section{Shelf backscatter distribution}

Three intervals or classes of backscatter intensity (BS) have been defined (Fig. 6): a) High-backscatter intensity (from -9.36 to $-18 \mathrm{~dB}$ ); b) Medium-backscatter intensity (from -18 to $-24 \mathrm{~dB}$ ); and c) Low-backscatter intensity (from -24 to $-32.69 \mathrm{~dB}$ ) (Fig. 6 and Table 2).

The correlation between backscatter intensity and mean grain size is depicted in a scatter plot (Fig. 6). The arithmetic mean was used to calculate the mean grain size of the surficial sediments:

$$
A M=\sum_{i=1}^{n} C M^{*} f_{i}
$$

where $A M$ represents the arithmetic mean of the grain size, $n$ the granulometric range number, $C M$ the expres- sion of the interval defined by

$$
C M=\frac{L_{s}+L_{i}}{2}
$$

where $L s$ and $L i$ are the upper and lower limits of grain size of interval respectively, and $f_{i}$ the relative frequency of the class $i$.

A positive correlation $\left(\mathrm{R}^{2}=0.63\right)$ between backscatter intensity and mean grain size is found (Fig. 7). This correlation is given by the function $\mathrm{BS}=9.73 \mathrm{Ln}(\mathrm{AM})$ 21.43.

Based on the sediment size-backscatter correlation, we have characterized the distribution patterns of backscatter intensities (high, medium and low) and their associated sediment sizes (Table 2). 


\begin{tabular}{|c|c|c|c|c|c|}
\hline & $\begin{array}{c}\text { Backscatter intensity } \\
\text { intervals (dB) }\end{array}$ & $\begin{array}{l}\text { Grain size } \\
\text { (mm) }\end{array}$ & $\begin{array}{c}\% \\
\text { Gravel }\end{array}$ & $\begin{array}{c}\% \\
\text { Sand }\end{array}$ & $\begin{array}{c}\% \\
\text { Mud }\end{array}$ \\
\hline $\begin{array}{l}\text { HIGH } \\
\text { backscatter }\end{array}$ & -9.36 to -18 & 3.45 and 1.42 & $\begin{array}{c}2.42-70.21 \% \\
\mathbf{2 5 . 3 6 \%}\end{array}$ & $\begin{array}{c}29.26-97.35 \% \\
\mathbf{7 0 . 3 9 \%}\end{array}$ & $\begin{array}{l}0-24.35 \% \\
\mathbf{4 . 2 5} \%\end{array}$ \\
\hline $\begin{array}{l}\text { MEDIUM } \\
\text { backscatter }\end{array}$ & -18 to -24 & 1.42 and 0.77 & $\begin{array}{c}0.06-33.39 \% \\
\mathbf{4 . 9 7 \%}\end{array}$ & $\begin{array}{c}55.71-99.5 \% \\
\mathbf{8 0 . 8 7 \%}\end{array}$ & $\begin{array}{c}0.03-42.29 \% \\
14.12 \%\end{array}$ \\
\hline $\begin{array}{l}\text { LOW } \\
\text { backscatter }\end{array}$ & -24 to 32.69 & 0.77 and 0.21 & $\begin{array}{c}0-12.37 \% \\
\mathbf{0 . 8 0} \backslash \%\end{array}$ & $\begin{array}{c}23.27-95.53 \% \\
\mathbf{6 2 . 1 3} \backslash \%\end{array}$ & $\begin{array}{c}0.2-76.23 \% \\
\mathbf{3 7 . 0 6} \%\end{array}$ \\
\hline
\end{tabular}

Table 2: Correlation between the backscatter classification and sedimentological parameters (grain size, minimum and maximum percentages of gravel, sand and mud) in the study area. Mean values of percentages of gravel, sand and mud indicated in bold.

Tabla 2: Correlación entre la clasificación de la reflectividad y los parámetros sedimentológicos (tamaño de grano, valor mínimo y máximo de los porcentajes de grava, arena y fango) en el área de estudio. En negrita se indica los valores medios de los porcentajes de grava, arena y fango.

\subsection{Correlation between backscatter intensities and grain sizes}

a) High-backscatter intensity. This backscatter interval ranges from -9.36 to $-18 \mathrm{~dB}$ (Table 2). These backscatter values correspond with the grain size interval between $3.45 \mathrm{~mm}$ (pebbles) and $1.42 \mathrm{~mm}$ (very coarse sands). The zones with high backscatter intensity show a strong dominance of sands $(>70 \%)$, with lesser gravels $(25 \%$, Table 2, Fig. 6).

b) Medium-backscatter intensity. This backscatter intensity interval ( -18 to $-24 \mathrm{~dB})$ is associated with grain sizes between $1.42 \mathrm{~mm}$ (very coarse sands) and $0.77 \mathrm{~mm}$ (coarse sands) (Table 2). The zones with medium-backscatter intensities exhibit sandy sediments, mixed either with gravels $(>34 \%)$ or with muds $(<42.29 \%)$ (Table 2 , Fig. 6).

c) Low-backscatter intensity. The backscatter intensity varies between -24 and $-32.69 \mathrm{~dB}$, and is associated with a grain size range between $0.77 \mathrm{~mm}$ (coarse sands) and $0.21 \mathrm{~mm}$ (fine sands) (Table 2). This backscatter class observes the highest mud contents (locally above 50\%) and very low gravel contents (Table 2, Fig. 6).

\subsection{Across-shelf distribution of backscatter intensities}

The across-shelf backscatter distribution shows that shallow waters $(<25 \mathrm{~m})$ are covered by high and medium backscatter strengths (Fig. 6). Mid-shelf water depths between 25-75 m mostly exhibit irregular patches of medium and low backscatter. Some exceptions to this general trend are: (a) the stretch between the Verde River and the Carchuna Canyon, where low reflectivity values are observed in 25-75 $\mathrm{m}$ water depths and (b) the eastern part of the study area shows high to medium backscatter values in 25-75 m water depths (Fig. 6). Medium to high backscatter values are usually found at water depths higher than $75 \mathrm{~m}$. However, some distal areas may show low backscatter strengths, such as the stretches between the Chillar and Jate rivers, between the Seco River and the Carchuna Canyon and between the Haza de Trigo and Huarea streams.

\subsection{Along-shelf distribution of backscatter intensities}

In accordance with the grain size distribution, we also depict the backscatter distribution in both sectors (western and eastern) (Fig. 6).

\section{Western sector}

The western sector is mainly covered by low-to-medium reflectivity values, although in shallow water $(<25$ $\mathrm{m}$ ) high and medium backscatter zones alternate laterally (Fig. 6-a1, a2). The most significant stretch of high backscatter in shallow water occurs between the Motril Port and the Carchuna Canyon.

In deeper water $(>25 \mathrm{~m})$ a low backscatter patch occurs on the inner shelf in the western termination of the study area. To the east, a clear reduction of backscatter values is observed. The shelf between the Güi and Chillar rivers mostly exhibits medium backscatter values, with a major high backscatter patch off the Torrox River. The stretch between the Chillar and Seco rivers mostly displays medium backscatter values, with two elongated coast-parallel low reflectivity patches separated by a narrow medium-reflectivity band extending from the Chillar to Jate rivers. The shelf sector between the Seco River and the Carchuna Canyon is covered by an extensive low reflectivity patch.

\section{Eastern sector}

The eastern sector mainly exhibits high-to-medium backscatter values (Fig. 6-b1, b2). Most of the infralittoral $(<25 \mathrm{~m})$ shows high backscatter. The most exten- 
Fig. 6.- Imagery of surficial backscatter intensities in the study area: (a1) filtered backscatter data in the western sector; (a2) classified backscatter data in the western sector; (a3) filtered backscatter data in the eastern sector; (a2) classified backscatter data in the eastern sector. Pie charts represent percentages of gravel, sand and mud in surficial sediment along the continental shelf. See location of the sector in figure 4. Fluvial systems are indicated by numbers 1-12. See location in Fig. 1.

Fig. 6.- Imagen de la intensidad superficial de la reflectividad en el área de estudio: (a1) reflectividad con los datos filtrados en el sector occidental; (a2) reflectividad clasificada en el sector occidental; (b1) reflectividad con los datos filtrados en el sector oriental; (b2) reflectividad clasificada en el sector oriental En los diagramas circulares se representan los porcentajes en grava, arena y fango de las muestras de sedimento superficiales a lo largo de la plataforma continental. Ver localización de los sectores en la figura 4 . Los sistemas fluviales se indican con los números del 1-12. Ver localización en la Fig.1.

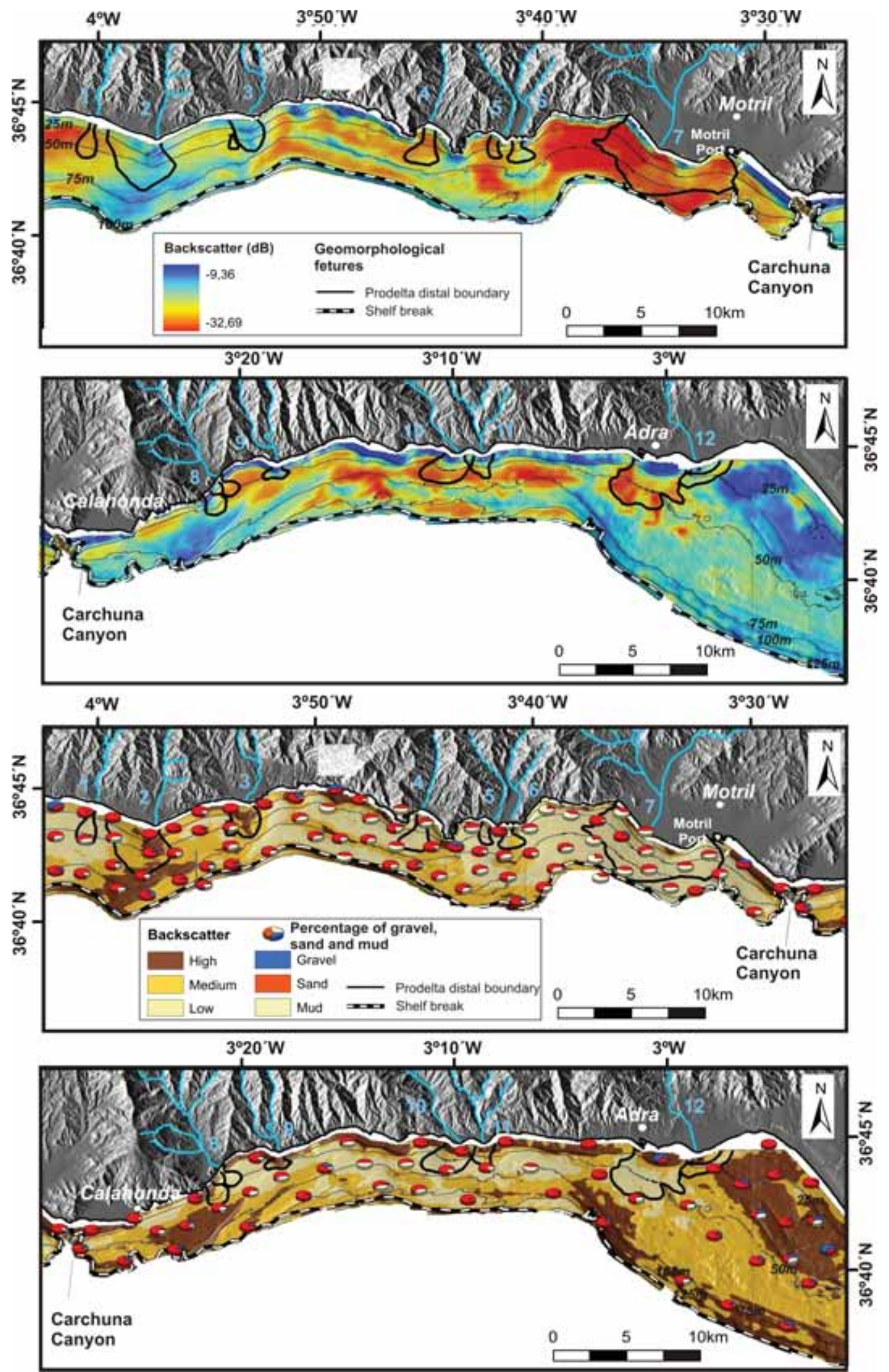

study area at water depths higher than $70 \mathrm{~m}$. In the transitional sector between the Gualchos Stream and the Adra River, there are two main low backscatter bands trending W-E and surrounded by medium backscatter values; a

shallower, relatively continuous but irregular band occurs sive high backscatter patch occurs to the east of the Adra River, covering the inner shelf up to $50 \mathrm{~m}$ water depth. In deeper mid-to-outer shelf water depths, zones with high backscatter occurs off the Gualchos Stream, between 50 and $75 \mathrm{~m}$ water depth, and in the easternmost part of the 


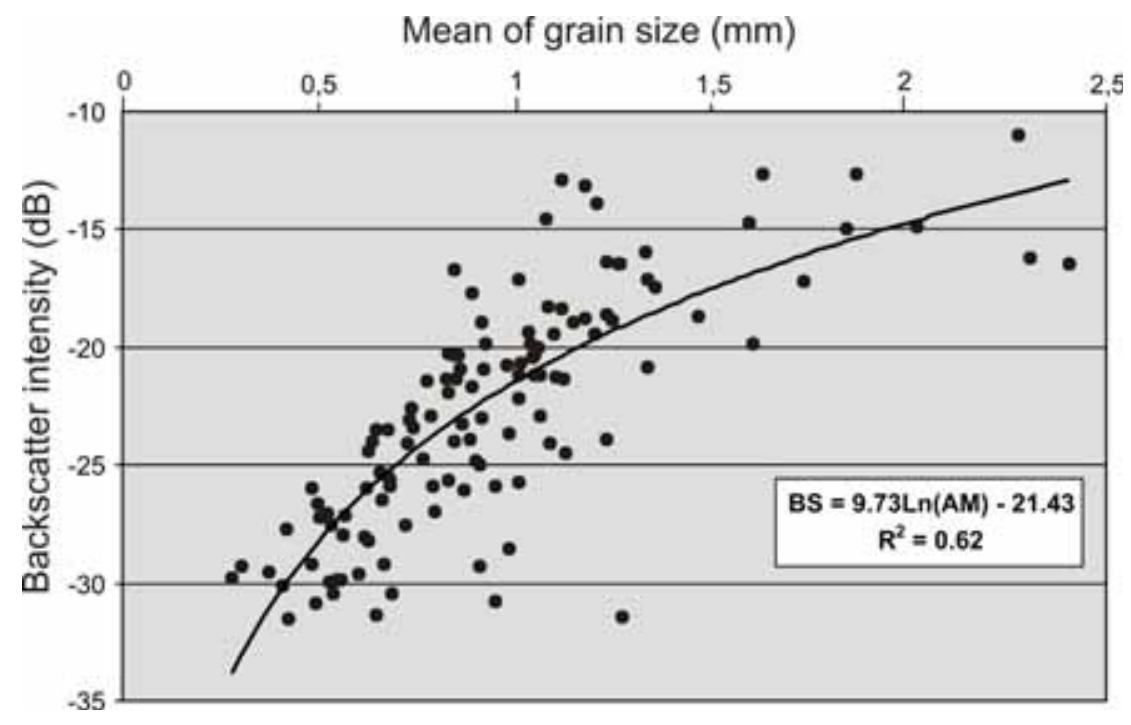

Fig.7.- Plot showing the relationship between backscatter intensity (BS) versus average grain size (AM) of surficial sediment samples.

Fig. 7.- Representación de la relación entre la intensidad de la reflectividad (BS) frente al tamaño medio de grano (AM) de las muestras de sedimento superficial.

at 50-75 $\mathrm{m}$ water depth, and a more discontinuous band occurs at around $100 \mathrm{~m}$ water depth.

\section{Current patterns and bed shear stress values}

Simulation results depict the distribution maps of depth-averaged current velocities matched with current direction vectors and of bed shear stress for two endmember situations (easterlies and westerlies dominance). Although wind speeds are similar for both main wind directions, both depth-averaged current velocity and bed shear-stress values are higher under easterlies dominance. Across-shelf, the maximum current velocity and bed shear-stress values occur up to $25 \mathrm{~m}$ water depth; basinward, the shelf break establishes a net boundary witnessing a significant current velocity decrease (Figs. $8,9)$. Along-shelf, higher values of both variables occur in the eastern sector.

\subsection{Western sector}

The most common depth-averaged current velocities on the western sector are lower than $0.1 \mathrm{~m} \mathrm{~s}^{-1}$. Maximum depth-averaged currents velocities $\left(>0.2 \mathrm{~m} \mathrm{~s}^{-1}\right)$ usually occurs at water depths less than $25 \mathrm{~m}$. On average, shelf current velocities are higher under easterlies dominance.

Maximum current velocities during both easterlies and westerlies dominance occur between Torrox and Chillar rivers, with velocities higher than $0.2 \mathrm{~m} \mathrm{~s}^{-1}$ in the nearshore (Fig. 8-a1). Under easterlies dominance, shelf sectors between the Seco and Verde rivers and the Guadalfeo River and the Carchuna Canyon are also affected by relatively high current velocity values (above $0.1 \mathrm{~m} \mathrm{~s}^{-1}$ ) (Fig. 8 -a1). During easterlies/westerlies dominance, the minimum velocity values can be observed in the westernmost part of the study area $\left(<0.03 \mathrm{~m} \mathrm{~s}^{-1}\right)$ and in the shelf sector between the Verde and Guadalfeo rivers (Fig. 8-a1, a2).

The bed shear stress exhibits a similar pattern (Fig. 9-a1, a2). The maximum values $\left(0.2 \mathrm{~N} \mathrm{~m}^{-2}\right)$ occur in the infralittoral zones $(<25 \mathrm{~m})$ between the Torrox and Chillar rivers irrespectively of wind dominance (Fig. 9-a1, a2). High values also occur between the Motril Port and the Carchuna Canyon under easterlies dominance (Fig. 9-a1).

\subsection{Eastern sector}

In the eastern sector, shelf currents exhibit different patterns along-shelf. The shelf between the Carchuna Canyon and the Haza de Trigo Stream is particularly affected by currents under easterlies dominance, as average currents flow westward with velocities higher than $0.15 \mathrm{~m} \mathrm{~s}^{-1}$, and even higher than $0.2 \mathrm{~m} \mathrm{~s}^{-1}$ in the nearshore (Fig. 8a). Under westerlies dominance, current conditions are weaker on this shelf, with northeastward flows barely reaching 0.1 $\mathrm{m} \mathrm{s}^{-1}$ (Fig. 8-b2).

The shelf between the Haza de Trigo Stream and the shelf widening to the west of Adra shows the less energetic current conditions in the eastern sector. There, maximum current velocities (above $0.2 \mathrm{~m} \mathrm{~s}^{-1}$ ) occur at water depths less than $25 \mathrm{~m}$. The rest of the shelf exhibits much lower current velocities (around $0.1 \mathrm{~m} \mathrm{~s}^{-1}$ ), with alternating directions according to wind dominance (Fig. 8-b1, b2).

The easternmost shelf shows the most energetic current conditions in the study area, as most of the shelf is affected by current velocities around $0.2 \mathrm{~m} \mathrm{~s}^{-1}$ during easterlies and westerlies dominance (Fig. 8-b1, b2). During easterlies dominance, velocity values near $0.2 \mathrm{~m} \mathrm{~s}^{-1}$ can be found up to the shelf break (Fig. 8-b1). During westerlies dominance, current velocities are slightly less intense, as 
maximum values near $0.2 \mathrm{~m} \mathrm{~s}^{-1}$ mainly occur on the inner shelf, whereas the outer shelf shows current velocity values below $0.15 \mathrm{~m} \mathrm{~s}^{-1}$ (Fig. 8-b2).

The distribution of bed shear stress in the eastern sector documents more energetic conditions affecting deeper areas during easterlies dominance (Fig. 9). The maximum values $\left(>0.2 \mathrm{~N} \mathrm{~m}^{-2}\right)$ occur at water depths less than $25 \mathrm{~m}$. Along-shelf, the highest bed shear-stress values are found between the Carchuna Canyon and the Gualchos Stream and to the east of the Huarea Stream in the easternmost part of the study area (Fig. 9-a1, b1).

\section{Discussion}

This study constitutes one of the first approaches linking the surficial sediment-backscatter response and the intensity of the hydrodynamic regime in shallow waters. In the Alboran Sea, previous insights linking seafloor backscatter responses with recent sedimentary environments have been conducted on deeper slope settings, where the interaction between geological processes (hemipelagic, volcanic and turbiditic sedimentation) (Lo Iacono et al., 2008) differs substantially from the dominant processes active on the shelf.

A positive correlation $\left(\mathrm{R}^{2}=0.63\right)$ between surficial grain sizes and backscatter intensities was found in the study area, which is in agreement with the observations reported in other sandy-dominated shallow-water environments (Davis et al., 1996; Goff et al., 2000; Kostylev et al., 2001; Collier and Brown, 2005; Ferrini and Flood, 2006; Lathrop et al., 2006; De Falco et al., 2010). Thus, levels of backscatter (high, medium and low) broadly correspond with sandy granulometric classes, with variable amounts of other textures, such as gravels and muds. As a consequence, the lateral changes in backscatter mainly reflect the changes in composition from gravel to mud in a sandy sea-floor environment.

\subsection{Across- and along-shelf sediment and backscatter changes}

Previous accounts of the surficial sediment distribution of the northern shelf of the Alboran Sea are simple, as they consider muddy prodeltaic deposits and poorly-sorted sandy relict facies (Ercilla et al., 1994). The combination of surficial sediment data and backscatter intensities provides a much improved picture of recent, surficial sedimentary processes actively forming the most surficial shelf sediment cover.

Across-shelf, there is a difference between the shallowest area ( $<25 \mathrm{~m}$ water depth) and the rest of the shelf, but not a well-defined seaward trend. In water depths deeper than $25 \mathrm{~m}$, granulometric and backscatter across-shelf changes are not evident. This pattern contrasts with the across-shelf sediment patterns reported in other wavedominated shelves, such as the southeastern Australian shelf (Griffin et al., 2008). There, sediment mobilization is considered to be mainly led by wave energy, resulting in across-shelf grain-size gradations. In the study area, a laterally continuous coarse-grained (sandy gravels and sands) and high backscatter infralitttoral environment (above $25 \mathrm{~m}$ water depth) is bounded seaward by an offlap break which is characteristic of shallow-water wedges in the northern margin of the Alboran Sea, such as prodeltas and IPWs (Hernández-Molina et al., 2000; FernándezSalas, 2008). The proximal coarse-grained granulometry and high backscatter response would reflect the leading influence of storm-weather hydrodynamic conditions on the infralittoral, both during easterlies and westerlies dominance, with maximum current velocities $(>0.2 \mathrm{~m}$ $\left.\mathrm{s}^{-1}\right)$ and the highest values of bed shear stress $(>0.2 \mathrm{~N}$ $\mathrm{m}^{-2}$ ). This bed shear-stress value represents the threshold for motion of grains with diameters higher than $0.05 \mathrm{~mm}$ (Soulsby, 1997). Direct current measurements made off Marbella (located about $80 \mathrm{~km}$ to the west of the western boundary of the study area) indicated variable velocities lower than $0.3 \mathrm{~m} \mathrm{~s}^{-1}$ (Janopaul and Frisch, 1984). Those values are therefore consistent with our estimations in the study area (i.e., maximum current velocities around 0.2 $\mathrm{m} \mathrm{s}^{-1}$ ).

The dominance of coarse-grained facies in similar inner shelf settings (water depths lower than $30 \mathrm{~m}$ ) is linked to the entrainment of sandy sediments and to the remobilization and seaward transport of fine-grained facies by storm waves (Pickrill, 1983; Wright et al., 1991; Dunbar and Barrett, 2005; Griffin et al., 2008; Storlazzi and Reid, 2010).

In the study area, along-shelf sediment composition and backscatter gradients are more significant. The along-shelf gradation seems to be dictated at first by the Carchuna Canyon that dissects completely the shelf, preventing from significant lateral sediment transport. In addition, local sediment supplies combined with bidirectional currents resulting from the alternance of easterlies and westerlies also leave an imprint. Indeed, the study area receives the contribution of a number of small mountainous rivers whose most significant sedimentation events occur during wet storm conditions.

The shelf located to the west of the Carchuna Canyon is dominated by the terrigenous sediment contributions of the major regional river (the Guadalfeo River), as well as the added contributions of several small rivers (Güí, 

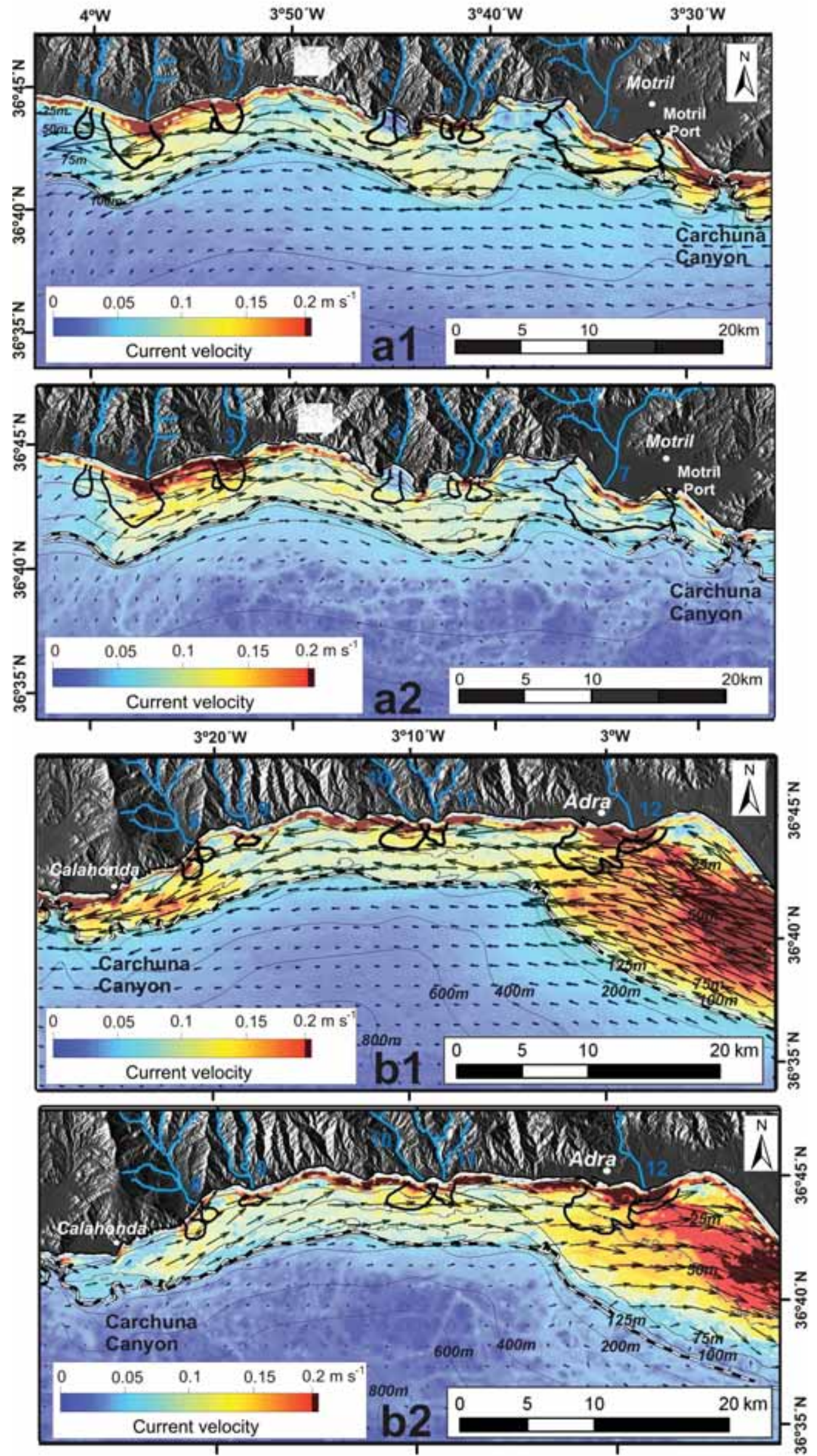

Fig. 8.- Mapping of direction and depth-averaged current speed $(\mathrm{m} / \mathrm{s})$ in the western and eastern sectors: (a1) easterlies dominance in the western sector; (a2) westerlies dominance in the western sector; (a3) easterlies dominance in the eastern ector; (a4) westerlies dominance in the eastern sector. See location of the sector in figure 4. Fluvial systems are indicated by numbers 1-12. See location in Fig. 1.

Fig. 8.- Cartografía de la dirección y velocidad media de la corriente $(\mathrm{m} / \mathrm{s})$ en los sectores occidental y oriental: (a1) bajo condiciones de vientos de levante en el sector occidental; (a2) bajo condiciones de vientos de poniente en el sector occidental; (b1) bajo condiciones de vientos de levante en el sector oriental; (b2) bajo condiciones de vientos de poniente en el sector oriental. Ver localización de los sectores en la figura 4. Los sistemas fluviales se indican con los números del 1-12. Ver localización en la Fig. 1. 
Fig. 9.- Mapping of the bed shear stress $\left(\mathrm{N} \mathrm{m}^{-2}\right)$ in the western and eastern sectors during contrasting wind dominance: (a1) easterlies dominance in the western sector; (a2) westerlies dominance in the western sector; (a3) easterlies dominance in the eastern sector; (a4) westerlies dominance in the eastern sector. See location of the sectors in figure 4. Fluvial systems are indicated by numbers 1-12. See location in Fig. 1.

Fig. 9.- Cartografía de la tensión tangencial del fondo $\left(\mathrm{N} \mathrm{m}^{-2}\right)$ en los sectores occidental y oriental durante diferentes condiciones de viento: (a1) bajo condiciones de vientos de levante en el sector occidental; (a2) bajo condiciones de vientos de poniente en el sector occidental; (b1) bajo condiciones de vientos de levante en el sector oriental; (b2) bajo condiciones de vientos de poniente en el sector oriental. Ver localización de los sectores en la figura 4. Los sistemas fluviales se indican con los números del 1-12. Ver localización en la Fig. 1.
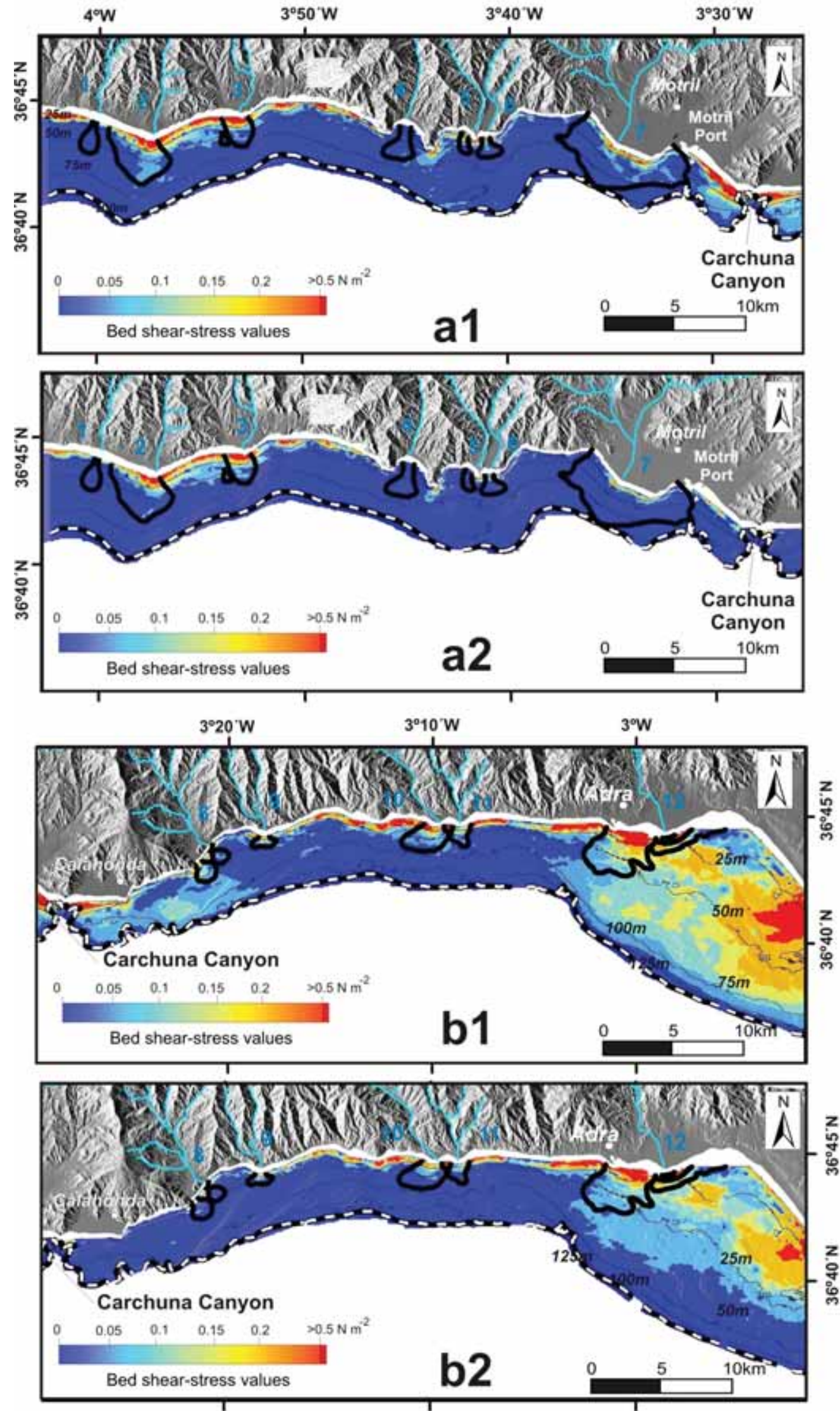
Torrox, Chillar, Jate, Seco and Verde rivers). As a consequence, surficial shelf sediments are dominated by muddy sands that generate medium to low backscatter intensities. The relationship between lower backscatter values with finer sediments is consistent with the results of many studies (e.g., Goff et al., 2000, 2004; Collier and Brown, 2005; Ferrini and Flood, 2006). In contrast, the shelf located to the east of the Carchuna Canyon is clearly dominated by the hydrodynamic regime, as shelf currents and bed shear-stress values are stronger than in the western sector, and terrigenous supplies are less important. The more intense oceanographic regime is related to the slight dominance of easterly-driven currents, leaving the western sector more protected to the dominant activity of westward currents. In addition, the existence of a significant shelf widening in the eastern part of the study area could also favour the interaction of shelf currents with the seafloor. On this wide shelf, the contribution of the second regional river (the Adra River) in terms of discharge would be moderate, as their sediment left over would be restricted to the inner shelf. The rest of the eastern shelf would only receive the contributions of ephemeral, seasonal streams with discontinuous flows (Gualchos, Haza de Trigo, Albuñol and Huarea).

\subsection{Small-scale sediment variability and backscatter zonation}

At a finer scale, the match found between the surficial sediment composition and the backscatter intensity enables us to distinguish a high lateral variability of seafloor sedimentation and different depositional/erosional shelf regimes with a distinctive backscatter response (high, medium and low). These relationships have been evidenced in estuarine settings (Nitsche et al., 2004), but most notably along sectors of the California Shelf, such as the Monterey Bay (Edwards, 2002; Eittreim et al., 2002), or the Eel Shelf (Sommerfield and Nittrouer, 1999), where flood-dominated sectors are juxtaposed with storm-dominated sectors. Shelf dissection by submarine canyons favours the lateral compartimentation in the California Shelf (Eittreim et al., 2002). In flood-dominated sectors, abundant and episodic sediment supply is provided by flood-prone mountainous rivers that bypass the inner shelf and deposit in the middle shelf, generating fine-grained depocenters. Those deposits laterally evolve to shelf sectors dominated by along-shelf transport processes induced by storms, generating laterally extensive muddy belts, or coarse sands deposits in areas with negligible fine-grained inputs (Edwards, 2002).

In the study area, three main shelf environments could be distinguished, storm-dominated, mixed and fluvially- dominated; these environments are defined by the distinct interaction between shelf current patterns and local fluvial supplies:

a) Storm-dominated environments. High backscatter intensities mainly produced by gravelly sands show a consistent spatial correlation with the intensity of shelf currents, as they occur in the locations where current velocity and bed shear-stress values are higher. These would represent shelf settings mainly dominated by storms, and subjected to periodic remobilisation and winnowing. Similar shelf environments have been described in the California Shelf, where high-energy bottom currents cause the remobilization of modern mud deposits, leaving transgressive lag deposits exposed at the seafloor in areas that lack fine sediment sources (Eittreim et al., 2002).

Erosional sedimentary responses are more extensive and significant at the locations where shelf currents reach the highest velocities, such as (1) the wide easternmost shelf of the study area (affected both by eastward and westward currents), (2) the shelf between the Carchuna Canyon and the Haza de Trigo Stream, mainly influenced by westward currents, and (3) the shelf between the Torrox and Chillar rivers, mainly influenced by eastward currents. In general, those high-energy shelf environments broadly occur off wide protuberances, where current-seafloor interaction is enhanced.

b) Mixed-energy depositional environments. Those environments occur in sandy shelf sectors developing elongated along-shelf medium backscatter distributions that suggest linear sediment sources. In the California Shelf, similar elongated depocenters show higher lateral continuity, revealing a higher efficiency of along-shelf transport processes, as the majority of the along-shelf sediment transport is related with strong storm events (Ogston and Sternberg, 1999; Edwards, 2002) and coupling with flooding events (Sommerfield and Nittrouer, 1999). In the study area, however, those environments would be subjected to a less effective oceanographic dispersal system due to weak oceanographic conditions (with maximum velocity values below $0.15 \mathrm{~m} \mathrm{~s}^{-1}$ and bed shear-stress values below $0.2 \mathrm{~N} \mathrm{~m}^{-2}$ ) combined with moderate to low fluvial supplies, as they tend to occur off small rivers (between the Chillar and Verde rivers) in the western sector and off ephemeral streams (between the Gualchos Stream and the Adra River) in the eastern sector. Those fluvial systems exhibit drainage basins of tens of $\mathrm{km}^{2}$ and river lengths between 8 and $25 \mathrm{~km}$, with low sediment supplies (mean sediment load is estimated at $0.4 \mathrm{~kg} \mathrm{~s}^{-1}$ for the case of the Verde River) (Liquete et al., 2005).

The Adra River also develops a medium backscatter fingerprint in spite of the higher size of the catchment 
(i.e., the drainage basin extends for $750 \mathrm{~km}^{2}$, and the river length is $51.4 \mathrm{~km}$ ) and more significant sediment contribution (the mean sediment load is $4.8 \mathrm{~kg} \mathrm{~s}^{-1}$ ). In addition, this river is particularly outstanding by its extremely high sediment yields (more than $200 \mathrm{t} \mathrm{km}^{-2} \mathrm{yr}^{-1}$ ), attributed to an increase in regional erosion and torrential character to the east (Liquete et al., 2005). The fact that the Adra River generates a sediment-backscatter response very similar to that generated by much smaller rivers would imply that the fluvial supply is obliterated in this relatively wide shelf segment by hydrodynamic forcing, as shelf bed shear stress attains its maximum values at this location. Those high current velocities could be conductive to the generation of gravity-driven, downslope transport of relatively fine sediments, as documented in numerous deltaic settings, like the shelf off the Eel River, northern California (Wright et al., 2001). This downslope transport of sediment may constitute a significant mechanism of across-shelf transport during storms (Wright and Friedrichs, 2006).

c) Fluvial-dominated depositional environments. Low backscatter intensities are mainly restricted to the west of the Carchuna Canyon, in relation with the dominance of muddy sands. The prevalence of those relatively finegrained facies across the shelf would indicate the main influence of river-derived sediment plumes, as documented in several settings of the California margin, such as Monterey Bay (Edwards, 2002; Eittreim et al., 2002) and the Eel Shelf (Goff et al., 1999), and off the Waiapu River, New Zealand (Wadman and McNinch, 2008). Those shelves receive greater-than-normal sediment contributions because fluvial delivery is made through steep, mountainous rivers (Storlazzi and Reid, 2010).

In comparison with the California Shelf, in the study area fluvially-derived deposits tend show a coarser composition with substantial amounts of sands. Although the physiographic settings are similar (i.e., small and steep drainage basins), a extreme torrential character for most of the rivers draining into the Alboran Sea would increase the availability of easily erodible materials, favouring the occurrence of hyperpycnal flows (Liquete et al., 2005; Urgeles et al., 2011).

Morphological indicators accounting for the occurrence of hyperpycnal flows in high-energy deltaic settings include eroded channels (Mitchell, 2005) and seafloor crenulations (Urgeles et al., 2011). In the study area, straight channels occur in several shallow prodeltas, such as Güí, Jate, Verde and Seco river prodeltas. In addition, seafloor undulations have been documented in numerous prodeltaic settings along the study area, where a relationship between the aspect ratio $(\mathrm{L} / \mathrm{H})$ and discharge characteristics was found (Fernández-Salas et al., 2007;
Bárcenas et al., 2009).

Amongst all the deltaic systems in the study area, the Guadalfeo River represents the major regional source (basin area of more than $1,300 \mathrm{~km}^{2}$, river length of 72.5 $\mathrm{km}$ and mean sediment load of $2.7 \mathrm{~km} \mathrm{~s}^{-1}$ according to Liquete et al. (2005)). Here, relatively high current velocity and bed shear-stress values less than $0.1 \mathrm{~N} \mathrm{~m}^{-2}$ (particularly during easterlies dominance) are not able to winnow the sediments and to remobilize the finer grain size fractions. Another factor to consider is the sheltering effect provided by physiographic boundaries such as the Carchuna Canyon and the landward coastal promontory, which would subdue the activity of oceanographic and storm-related processes, as evidenced in Monterey Bay (Edwards, 2002).

\section{Conclusions}

The distribution of surface sediments shows a good correlation with the backscatter response over a wide segment of the northern shelf of the Alboran Sea. High, intermediate and low backscatter responses broadly correspond with sandy sediments with variable amounts of accessory grain sizes (from gravels to muds in consonance with decreasing backscatter intensities).

The surficial sediment distribution of the shelf under consideration differs from other surficial sediment gradation patterns, as along-shelf changes are more significant that across-shelf. Off from the coast, the most consistent pattern is provided by a high backscatter infralittoral band of gravelly sands generated by storm conditions, with maximum current velocities $\left(>0.2 \mathrm{~m} \mathrm{~s}^{-1}\right)$ and the highest bed shear-stress $\left(>0.2 \mathrm{~N} \mathrm{~m}^{-2}\right)$ occurring during both easterlies and westerlies dominance. Seaward, across-shelf changes in surficial sediment-backscatter patterns are less conspicuous. A lateral segmentation is evident, primarily conditioned by the Carchuna Canyon head dissecting the shelf but also by the interaction between an active, bidirectional flow regime and local fluvial supplies from mountainous, small rivers. The shelf sector to the west of the canyon is dominated by the contribution of fluvial systems; in contrast, the shelf sector to the east of the canyon is mainly influenced by the hydrodynamic regime.

At a small scale, the backscatter response was indicative of variable depositional/erosional shelf regimes. Three main environments were defined: storm-dominated, mixed and fluvially dominated. Maximum current velocity and bed shear-stress values show a very high correlation with gravelly sands and high backscatter intensities, thus strongly controlling the location of stormdominated environments. Mixed and fluvially-dominated environments occur in response to the competing influ- 
ence of fluvial supplies and moderate hydrodynamic conditions. This results in contrasting surficial backscatter fingerprints of the two main regional sediment sources (the Guadalfeo and Adra rivers).

\section{Acknowledgements}

Multibeam data were collected within the framework of the project ESPACE (Estudio de la Plataforma Continental Española), executed by the "Instituto Español de Oceanografía (IEO)" and the "Secretaría General del Mar (SGM)". This work represents a contribution to the project entitled "Modelado, Simulación Numérica y Análisis del Transporte de Sedimentos en los Abanicos Submarinos de los Ríos de Andalucía Oriental" (MOSAICO acronym) funded by the "Junta de Andalucía" (http:// anamat.cie.uma.es/mosaico/). Constructive and detailed reviews were provided by Neil C. Mitchell (University of Manchester) and by an anonymous reviewer.

\section{References}

Bárcenas, P., Fernández-Salas, L. M., Macías, J., Lobo, F. J., Díaz del Río, V. (2009): Estudio morfométrico comparativo entre las ondulaciones de los prodeltas de los ríos de Andalucía Oriental. Revista de la Sociedad Geológica de España, 22: 43-56.

Brown, C. J., Todd, B. J., Kostylev, V. E., Pickrill, R. A. (2011): Image-based classification of multibeam sonar backscatter data for objective surficial sediment mapping of Georges Bank, Canada. Continental Shelf Research, 31: S110-S119. doi: 10.1016/j.csr.2010.02.009.

Campillo, A. C., Maldonado, A., Mauffret, A. (1992): Stratigraphic and tectonic evolution of the western Alboran Sea: Late miocene to recent. Geo-Marine Letters, 12: 165-172. doi: 10.1007/BF02084928.

Carvajal, R., Sanz de Galdeano, C. (2008): Aplicación de índices geomorfológicos al estudio de la cuenca del río Adra (Almería). Cuaternario y Geomorfología, 22: 17-31.

Castro, M., García-Rodríguez, J.A., González-Vida, J.M., Parés, C. (2006): A parallel 2D finite volume scheme for solving systems of balance laws with nonconservative products: Applications to shallow flows. Computer Methods in Applied Mechanics and Engineering, 195: 2788-2815. doi: 10.1016/j.cma.2005.07.007.

Collier, J. S., Brown, C. J. (2005): Correlation of sidescan backscatter with grain size distribution of surficial seabed sediments. Marine Geology, 214: 431-449. doi: 10.1016/j. margeo.2004.11.011.

Comas, M. C., García-Dueñas, V., Jurado, M. J. (1992): Neogene tectonic evolution of the Alboran Sea from MCS data. Geo-Marine Letters, 12: 157-164. doi: 10.1007/BF02084927.

Davis, K. S., Slowey, N. C., Stender, I. H., Fiedler, H., Bryant, W. R., Fechner, G. (1996): Acoustic backscatter and sediment textural properties of inner shelf sands, northeastern Gulf of Mexico. Geo-Marine Letters, 16: 273-278. doi: 10.1007/bf01204520.

De Falco, G., Tonielli, R., Di Martino, G., Innangi, S., Simeone, S., Michael Parnum, I. (2010): Relationships between multibeam backscatter, sediment grain size and Posidonia oceanica seagrass distribution. Continental Shelf Research, 30: 1941-1950. doi: 10.1016/j.csr.2010.09.006.

Dunbar, G. B., Barrett, P. J. (2005): Estimating palaeobathymetry of wave-graded continental shelves from sediment texture. Sedimentology, 52: 253-269. doi: 10.1111/j.13653091.2004.00695.x.

Edwards, B. D. (2002): Variations in sediment texture on the northern Monterey Bay National Marine Sanctuary continental shelf. Marine Geology, 181: 83-100. doi: 10.1016/ S0025-3227(01)00262-6.

Eittreim, S. L., Anima, R. J., Stevenson, A. J. (2002): Seafloor geology of the Monterey Bay area continental shelf. Marine Geology, 181: 3-34. doi: 10.1016/S0025-3227(01)00259-6.

Ercilla, G., Alonso, B., Baraza, J. (1994): Post-Calabrian sequence stratigraphy of the northwestern Alboran Sea (southwestern Mediterranean). Marine Geology, 120: 249-265. doi: 10.1016/0025-3227(94)90061-2.

Estrada, F., Ercilla, G., Alonso, B. (1997): Pliocene-Quaternary tectonic-sedimentary evolution of the NE Alboran Sea (SW Mediterranean Sea). Tectonophysics, 282: 423-442. doi: 10.1016/S0040-1951(97)00227-8.

Fernández-Salas, L.M. (2008). Los depósitos del Holoceno Superior en la plataforma continental del sur de la Península Ibérica: Caracterización morfológica y estratigráfica. Ph. D., Universidad de Cádiz, Cádiz, 277 p.

Fernández-Salas, L. M., Lobo, F. J., Sanz, J. L., Diaz-del-Rio, V., Garcia, M. C., Moreno, I. (2007): Morphometric analysis and genetic implications of pro-deltaic sea-floor undulations in the northern Alboran Sea margin, western Mediterranean Basin. Marine Geology, 243: 31-56. doi: 10.1016/j.margeo.2007.04.013.

Ferrini, V.L., Flood, R.D. (2006): The effects of fine-scale surface roughness and grain size on $300 \mathrm{kHz}$ multibeam backscatter intensity in sandy marine sedimentary environments. Marine Geology, 228 (1-4): 153-172. doi: 10.1016/j.margeo.2005.11.010.

Folk, R.L. (1954): The distinction between grain size and mineral composition in sedimentary rock nomenclature. Journal of Geology, 62 (4): 344-359.

Folk, R.L. (1974): Petrology of sedimentary rocks. Hemphills, Austin Tex: 170 pp.

Gadner, J.V., Field, M.E., Lee, H., Edwars, B.E., Masson, D.G., Kenyon, N., Kidd, R.B. (1991): Ground truthing $6.5-\mathrm{kHz}$ sidescan sonographs: what are we really imaging?. Jounal of Geophysical Research, 96: 5955-5974. doi: 10.1029/90jb02730.

Glynn, B., Brown, C., Rooney, S. (2008): Coincident swath acoustic backscatter and bathymetry for the interpretation of shallow-water sediment composition and processes. Journal of the Geological Society, 165: 597-607. doi: 10.1144/001676492006-186. 
Goff, J. A., Orange, D. L., Mayer, L. A., Hughes Clarke, J. E. (1999): Detailed investigation of continental shelf morphology using a high-resolution swath sonar survey: the Eel margin, northern California. Marine Geology, 154: 255-269. doi: 10.1016/S0025-3227(98)00117-0.

Goff, J. A., Olson, H. C., Duncan, C. S. (2000): Correlation of side scan backscatter intensity with grain size distribution of shelf sediments, New Jersey margin. Geo-Marine Letters, 20: 43-49. doi: 10.1007/s003670000032.

Goff, J. A., Kraft, B. J., Mayer, L. A., Schock, S. G., Sommerfield, C. K., Olson, H. C., Gulick, S. P. S., Nordfjord, S. (2004): Seabed characterization on the New Jersey middle and outer shelf: correlatability and spatial variability of seafloor sediment properties. Marine Geology, 209: 147-172. doi: 10.1016/j.margeo.2004.05.030.

Goy, J. L., Zazo, C., Dabrio, C. J. (2003): A beach-ridge progradation complex reflecting periodical sea-level and climate variability during the Holocene (Gulf of Almeria, Western Mediterranean). Geomorphology, 50: 251-268. doi: 10.1016/ S0169-555X(02)00217-9.

Griffin, J. D., Hemer, M. A., Jones, B. G. (2008): Mobility of sediment grain size distributions on a wave dominated continental shelf, southeastern Australia. Marine Geology, 252: 13-23. doi: 10.1016/j.margeo.2008.03.005.

Hamilton, E.L., Bachman, R.T. (1982): Sound velocity and related properties of marine sediments. Journal of the Acoustical Society of America, 72: 1891-1904. doi: 10.1121/1.388539.

Hernández-Molina, F. J., Somoza, L., Rey, J., Pomar, L. (1994): Late Pleistocene-Holocene sediments on the Spanish continental shelves: Model for very high resolution sequence stratigraphy. Marine Geology, 120: 129-174. doi: 10.1016/00253227(94)90057-4.

Hernández-Molina, F. J., Somoza, L., Rey, J. (1996): Late Pleistocene-Holocene high-resolution sequence analysis on the Alboran Sea continental shelf. In: M. De Batist, P. Jacobs, (eds.), Geology of Siliciclastic Shelf Seas. Geological Society, Special Publication 117, London: 139-154. doi: 10.1144/ gsl.sp.1996.117.01.08.

Hernández-Molina, F. J., Fernández-Salas, L. M., Lobo, F.J., Somoza, L., Díaz-del-Río, V., Alveirinho Dias, J.M. (2000): The infralittoral wedge: a new large-scale progradational sedimentary body in shallow marine environments. GeoMarine Letters, 20: 109-117. doi: 10.1007/s003670000040.

Jabaloy-Sánchez, A., Lobo, F.J., Azor, A., Bárcenas, P., Fernández-Salas, L.M., Díaz del Río, V., Pérez-Peña, J.V. (2010): Human-driven coastline changes in the Adra River deltaic system, southeast Spain. Geomorphology, 119 (1-2): 9-22. doi: 10.1016/j.geomorph.2010.02.004.

Jackson, D.R., Winebrenner, D.P., Ishimaru, A. (1986): Application of the composite roughness model to high-frequency bottom backscattering. Journal of the Acoustical Society of America, 79: 1410-1422. doi: 10.1121/1.393669.

Janopaul, M.M., Frisch, A.S. (1984): CODAR measurements of surface currents in the northwest Alboran Sea during the Donde Va experiment. Annales de Geophysique, 2: 443-448.

Jenks, G. F. (1967). The Data Model Concept in Statistical Mapping. International Yearbook of Cartography, 7: 186-190.
Kostylev, V. E., Todd, B. J., Fader, G. B. J., Courtney, R. C., Cameron, G. D. M., Pickrill, R. A. (2001): Benthic habitat mapping on the Scotian Shelf based on multibeam bathymetry, surficial geology and seafloor photographs. $M a-$ rine Ecology Progress Series, 219: 121-137. doi: 10.3354/ meps219121.

Lario, J., Zazo, C., Goy, J. L. (1999): Fases de progradación y evolución morfosedimentaria de la flecha litoral de Calahonda (Granada) durante el Holoceno. Estudios Geológicos, 55: 247-250.

Lathrop, R. G., Cole, M., Senyk, N., Butman, B. (2006): Seafloor habitat mapping of the New York Bight incorporating sidescan sonar data. Estuarine, Coastal and Shelf Science, 68: 221-230. doi: 10.1016/j.ecss.2006.01.019.

Liquete, C., Arnau, P., Canals, M., Colas, S. (2005): Mediterranean river systems of Andalusia, southern Spain, and associated deltas: A source to sink approach. Marine Geology, 222-223: 471-495. doi: 10.1016/j.margeo.2005.06.033.

Lo Iacono, C., Gràcia, E., Diez, S., Bozzano, G., Moreno, X., Dañobeitia, J., Alonso, B. (2008): Seafloor characterization and backscatter variability of the Almería Margin (Alboran Sea, SW Mediterranean) based on high-resolution acoustic data. Marine Geology, 250: 1-18. doi: 10.1016/j.margeo.2007.11.004.

Lobo, F. J., Fernandez-Salas, L. M., Moreno, I., Sanz, J. L., Maldonado, A. (2006): The sea-floor morphology of a Mediterranean shelf fed by small rivers, northern Alboran Sea margin. Continental Shelf Research, 26: 2607-2628. doi: 10.1016/j.csr.2006.08.006.

Lyard F., Lefevre F., Letellier T., Francis O. (2006): Modelling the global ocean tides: modern insights from FES2004. Ocean Dynamics, 56: 394-415. doi: 10.1007/s10236-0060086-x.

McMaster, R. 1997. In Memoriam: George F. Jenks (19161996). Cartography and Geographic Information Science, 24(1): 56-59.

Medialdea, T., Somoza, L., León, R., Farrán, M., Ercilla, G., Maestro, A., Casas, D., Hernández Molina, F.J., Fernández Puga, M.C., Alonso, B. (2008): Multibeam backscatter as a toll for sea-floor characterization and identification of oil spills in the Galicia Bank. Marine Geology, 249: 93-107. doi: 10.1016/j.margeo.2007.09.007.

Mitchell, N.C. (1991): Improving GLORIA images using Sea Beam data. Journal of Geophysical Research, 96: 337-351. doi: 10.1029/90jb01895.

Mitchell, N.C. (1993): A model for attenuation of backscatter due to sediment accumulations and its application to determine sediment thickness with GLORIA sidescan sonar. Journal of Geophysical Research, 98: 22477-22493. doi: 10.1029/93jb02217.

Mitchell, N.C. (1995): Representing backscatter fluctuations with a PDF convolution equation, and its application to study backscatter variability in side-scan sonar images. IEEE Transactions on Geoscience and Remote Sensing. 33(6): 1328-1331. doi: 10.1109/36.477190.

Mitchell, N. C. (2005): Channelled erosion through a marine dump site of dredge spoils at the mouth of the Puyallup Riv- 
er, Washington State, USA. Marine Geology, 220: 131-151. doi: 10.1016/j.margeo.2005.06.032.

Mitchell, N. C., Hughes Clarke, J. E. (1994): Classification of seafloor geology using multibeam sonar data from the Scotian Shelf. Marine Geology, 121: 143-160. doi: 10.1016/00253227(94)90027-2.

Muñoz, A., Ballesteros, M., Montoya, I., Rivera, J., Acosta, J., Uchupi, E. (2008): Alboran Basin, southern Spain, Part I. Geomorphology. Marine and Petroleum Geology, 25: 59-73. doi: 10.1016/j.marpetgeo.2007.05.003.

Nitsche, F. O., Bell, R., Carbotte, S. M., Ryan, W. B. F., Flood, R. (2004): Process-related classification of acoustic data from the Hudson River Estuary. Marine Geology, 209: 131145. doi: 10.1016/j.margeo.2004.05.023.

Ogston, A. S., Sternberg, R. W. (1999): Sediment-transport events on the northern California continental shelf. Marine Geology, 154: 69-82. doi: 10.1016/S0025-3227(98)00104-2.

Parrilla, G., Kinder, T., (1987): Oceanografía física del Mar de Alborán. Boletín del Instituto Español de Oceanografía, 4(1): 133-165.

Perkins, H., Kinder, T., La Violette, P. (1990): The Atlantic inflow in the Western Alboran Sea. Journal of Physical Oceanography, 20: 242-263. Doi: 10.1175/1520-0485(1990)020.

Pickrill, R. A. (1983): Wave-built shelves on some low-energy coasts. Marine Geology, 51: 193-216. doi: 10.1016/00253227(83)90104-4.

Puertos-del-Estado (2007). Clima Medio de Oleaje. Boya de Mar de Alborán. Conjunto de datos: Redext.

Sommerfield, C. K., Nittrouer, C. A. (1999): Modern accumulation rates and a sediment budget for the Eel shelf: a flooddominated depositional environment. Marine Geology, 154: 227-241. doi: 10.1016/S0025-3227(98)00115-7.

Soulsby, R. (1997): Dynamics of marine sands: A manual for practical applications. Thomas Telford Ltd., London, $249 \mathrm{p}$.

Storlazzi, C. D., Reid, J. A. (2010): The influence of El NiñoSouthern Oscillation (ENSO) cycles on wave-driven seafloor sediment mobility along the central California continental margin. Continental Shelf Research, 30: 1582-1599. doi: 10.1016/j.csr.2010.06.004.

Tintoré, J., La Violette, P. E., Blade, I., Cruzado, A. (1988): A Study of an Intense Density Front in the Eastern Alboran
Sea: The Almeria Oran Front. Journal of Physical Oceanography, 18: 1384-1397. doi: 10.1175/1520-0485(1988)018.

Urgeles, R., Locat, J., Schmitt, T., Hughes Clarke, J. E. (2002): The July 1996 flood deposit in the Saguenay Fjord, Quebec, Canada: implications for sources of spatial and temporal backscatter variations. Marine Geology, 184: 41-60. doi: 10.1016/S0025-3227(01)00303-6.

Urgeles, R., Cattaneo, A., Puig, P., Liquete, C., De Mol, B., Amblàs, D., Sultan, N., Trincardi, F. (2011): A review of undulated sediment features on Mediterranean prodeltas: distinguishing sediment transport structures from sediment deformation. Marine Geophysical Research, 32: 49-69. doi: 10.1007/s11001-011-9125-1.

Vargas-Yáñez, M., Sabates, A. (2007): Mesoscale high-frequency variability in the Alboran Sea and its influence on fish larvae distributions. Journal of Marine Systems, 68: 421438. doi: 10.1016/j.jmarsys.2007.01.004.

Vázquez, J. T. (2001): Estructura del margen continental del Mar de Alborán. Ph. D. Thesis, Universidad Complutense de Madrid, Madrid, $347 \mathrm{p}$.

Vázquez, J. T. (2005): El margen continental del Mar de Alborán. In: A. Martín-Serrano, (ed.), Mapa Geomorfológico de España y del margen continental. Instituto Geológico y Minero de España, Madrid: 191-198.

Wadman, H. M., McNinch, J. E. (2008): Stratigraphic spatial variation on the inner shelf of a high-yield river, Waiapu River, New Zealand: Implications for fine-sediment dispersal and preservation. Continental Shelf Research, 28: 865-886. doi: 10.1016/j.csr.2008.01.013.

Wright, L. D., Boon, J. D., Kim, S. C., List, J. H. (1991): Modes of cross-shore sediment transport on the shoreface of the Middle Atlantic Bight. Marine Geology, 96: 19-51. doi: 10.1016/0025-3227(91)90200-N.

Wright, L. D., Friedrichs, C. T., Kim, S. C., Scully, M. E. (2001): Effects of ambient currents and waves on gravitydriven sediment transport on continental shelves. Marine Geology, 175: 25-45. doi: 10.1016/S0025-3227(01)00140-2.

Wright, L. D., Friedrichs, C. T. (2006): Gravity-driven sediment transport on continental shelves: A status report. Continental Shelf Research, 26: 2092-2107. doi: 10.1016/j. csr.2006.07.008. 